\title{
Collaborative International Research in Clinical and Longitudinal Experience Study in NMOSD
}

Lawrence J. Cook, PhD, John W. Rose, MD, Jessica S. Alvey, MS, Anna Marie Jolley, BS, Renee Kuhn, BS, Brie Marron, BS, Melissa Pederson, MEd, Rene Enriquez, BS, Jeff Yearley, BA, Stephen McKechnie, MS, May H. Han, MD, Anna J. Tomczak, MS, Michael Levy, MD, PhD, Maureen A. Mealy, MScN, Jessica Coleman, BA, Jeffrey L. Bennett, MD, PhD, Ruth Johnson, BS, Myka Barnes-Garcia, BA, Anthony L. Traboulsee, MD, Robert L. Carruthers, MD, Lisa Eunyoung Lee, MSc, Julia J. Schubert, BS, Katrina McMullen, PhD, Ilya Kister, MD, Zoe Rimler, BS, Allyson Reid, BA, Nancy L. Sicotte, MD, Sarah M. Planchon, PhD, Jeffrey A. Cohen, MD, Diane Ivancic, CCRP, Jennifer L. Sedlak, BSN, Ilana Katz Sand, MD, Pavle Repovic, MD, PhD, Lilyana Amezcua, MD, MS, Ana Pruitt, BS, Erika Amundson, BA, Tanuja Chitnis, MD, Devin S. Mullin, BS, Eric C. Klawiter, MD, Andrew W. Russo, BS, Claire S. Riley, MD, Kaho B. Onomichi, MS, Libby Levine, RN, ANP-BC, Katherine E. Nelson, BA, Nancy M. Nealon, MD, Casey Engel, BA, Mason Kruse-Hoyer, MD, MA, Melanie Marcille, BA, Leticia Tornes, MD, Anne Rumpf, BS, Angela Greer, BS, Megan Kenneally Behne, AS, Renee R. Rodriguez, AS, Daniel W. Behne, MArch, Derek W. Blackway, BA, Brian Coords, MA, Terrence F. Blaschke, MD,

Judy Sheard, MPH, MA, Terry J. Smith, MD, Jacinta M. Behne, MA, and Michael R. Yeaman, PhD, on behalf of The Guthy-Jackson Charitable Foundation International Clinical Consortium (GJCF-ICC)

Neurol Neuroimmunol Neuroinflamm 2019;6:e583. doi:10.1212/NXI.0000000000000583

\section{Abstract}

\section{Objective}

To develop a resource of systematically collected, longitudinal clinical data and biospecimens for assisting in the investigation into neuromyelitis optica spectrum disorder (NMOSD) epidemiology, pathogenesis, and treatment.

\section{Methods}

To illustrate its research-enabling purpose, epidemiologic patterns and disease phenotypes were assessed among enrolled subjects, including age at disease onset, annualized relapse rate (ARR), and time between the first and second attacks.

\section{Results}

As of December 2017, the Collaborative International Research in Clinical and Longitudinal Experience Study (CIRCLES) had enrolled more than 1,000 participants, of whom $77.5 \%$ of the NMOSD cases and $71.7 \%$ of the controls continue in active follow-up. Consanguineous relatives of patients with NMOSD represented $43.6 \%$ of the control cohort. Of the 599 active cases with complete data, $84 \%$ were female, and $76 \%$ were anti-AQP4 seropositive. The majority were white/Caucasian (52.6\%), whereas blacks/African Americans accounted for 23.5\%, Hispanics/ Latinos 12.4\%, and Asians accounted for 9.0\%. The median age at disease onset was 38.4 years, with a median ARR of 0.5. Seropositive cases were older at disease onset, more likely to be black/African American or Hispanic/Latino, and more likely to be female.

\section{Conclusions}

Collectively, the CIRCLES experience to date demonstrates this study to be a useful and readily accessible resource to facilitate accelerating solutions for patients with NMOSD.

\author{
Correspondence \\ Dr. Cook \\ larry.cook@hsc.utah.edu
}




\section{Glossary}

AQP4 = aquaporin-4; ARR = annual relapse rate; CRC = Clinical Research Coordinator; EDSS = Expanded Disability Status Scale; GJCF = The Guthy-Jackson Charitable Foundation; ICC = International Clinical Consortium; IQR = interquartile range; MOG = myelin oligodendrocyte glycoprotein; NMOSD = neuromyelitis optica spectrum disorder; PSF = patient study file.

Neuromyelitis optica spectrum disorder (NMOSD) represents a chronic, potentially debilitating and life-threatening neuroinflammatory process primarily targeting the optic nerves, spinal cord, and brain. ${ }^{1-4}$ The typical clinical course of NMOSD is marked by multiple relapses resulting in cumulative neurologic disabilities. These events are interspersed with remissions from disease activity of variable duration. Heightened awareness of the disease among health care providers and the public and recent advances in diagnostic precision have increased estimates of worldwide NMOSD prevalence, reaching as high as 10 per 100,000 in some populations. ${ }^{5-8}$ This projection translates to more than 15,000 patients with NMOSD in the United States, suggesting that hundreds of thousands of cases exist worldwide. NMOSD disproportionately affects females (up to 7:1 femaleto-male ratio), with anti-aquaporin-4 (AQP4) antibody (hereafter referred to as anti-AQP4) positive disease having even greater propensity for women. ${ }^{9,10}$ Yet, many details regarding etiology, pathogenesis, risk factors, and demography of NMOSD are in need of greater understanding.

Although case series and observational studies suggest benefit from immunotherapy, to date no treatment of NMOSD has been proven safe and effective in prospective, double-masked and adequately powered clinical trials. ${ }^{11-13}$ Because of its rarity, insufficient access to well-characterized patient cohorts has historically hindered studies as has an absence of highfidelity preclinical models of human disease. Limitations in carefully standardized, longitudinal clinical research tools have also impeded investigation of NMOSD immunopathogenesis. However, 4 separate clinical trials have now reported positive results evaluating 3 compounds (eculizumab, satralizumab, and inebilizumab) in studies assessing efficacy in delaying or preventing relapses in NMOSD.

The Guthy-Jackson Charitable Foundation (GJCF) initiated an observational study of NMOSD in which patients and comparative controls are enrolled and evaluated longitudinally in a standardized manner. This study, known as Collaborative International Research in Clinical and Longitudinal Experience Studies (CIRCLES) for NMOSD, was launched in November 2013. In CIRCLES, participant clinical data, demographic profiles, and biospecimens were collected at geographically dispersed academic medical centers located throughout North America (figure 1).

The design and performance of the CIRCLES study are described here, along with initial data analysis illustrating the utility of its database and biorepository to advance scientific knowledge and clinical care in NMOSD. It is anticipated that this study will accelerate greater understanding of NMOSD and in turn the development of safe and effective therapies to benefit patients with NMOSD and perhaps those diagnosed with other autoimmune diseases.

\section{Methods}

\section{Clinical research standards}

\section{Human subjects protection}

Participant enrollment is conducted in accordance with the guidelines specified by the Office of Human Research Protections of the US Food and Drug Administration. A standardized protocol, manual of operations, patient study file (PSF), and informed consent or assent documents were approved by the institutional review board of each participating institution. Written and verbal consent or assent was obtained before beginning study procedures. The protocol and PSF were updated periodically.

\section{Study goals and design}

\section{Design}

CIRCLES is a prospective, multicenter, cross-sectional, and longitudinal study enabling comparisons of NMOSD cases and controls from which clinical data and biospecimens were collected using standardized methods. These were collected from cases at 6-month intervals and at least annually from control participants. When possible, clinical data and biospecimens were obtained from cases during or within 10 days following clinically confirmed relapses.

\section{Goals}

Two primary goals of CIRCLES include the following: (1) establish a cohort of patients with NMOSD and comparative controls who are longitudinally assessed at standardized intervals and (2) analyze acquired clinical data and biospecimens, thus improving knowledge of NMOSD and the patient experience.

\section{Sites}

Multiple study sites were established at academic institutions throughout North America (figure 1), each led by a clinical investigator/neurologist with expertise in NMOSD. Study sites were selected based on the size/activity of their NMOSD 


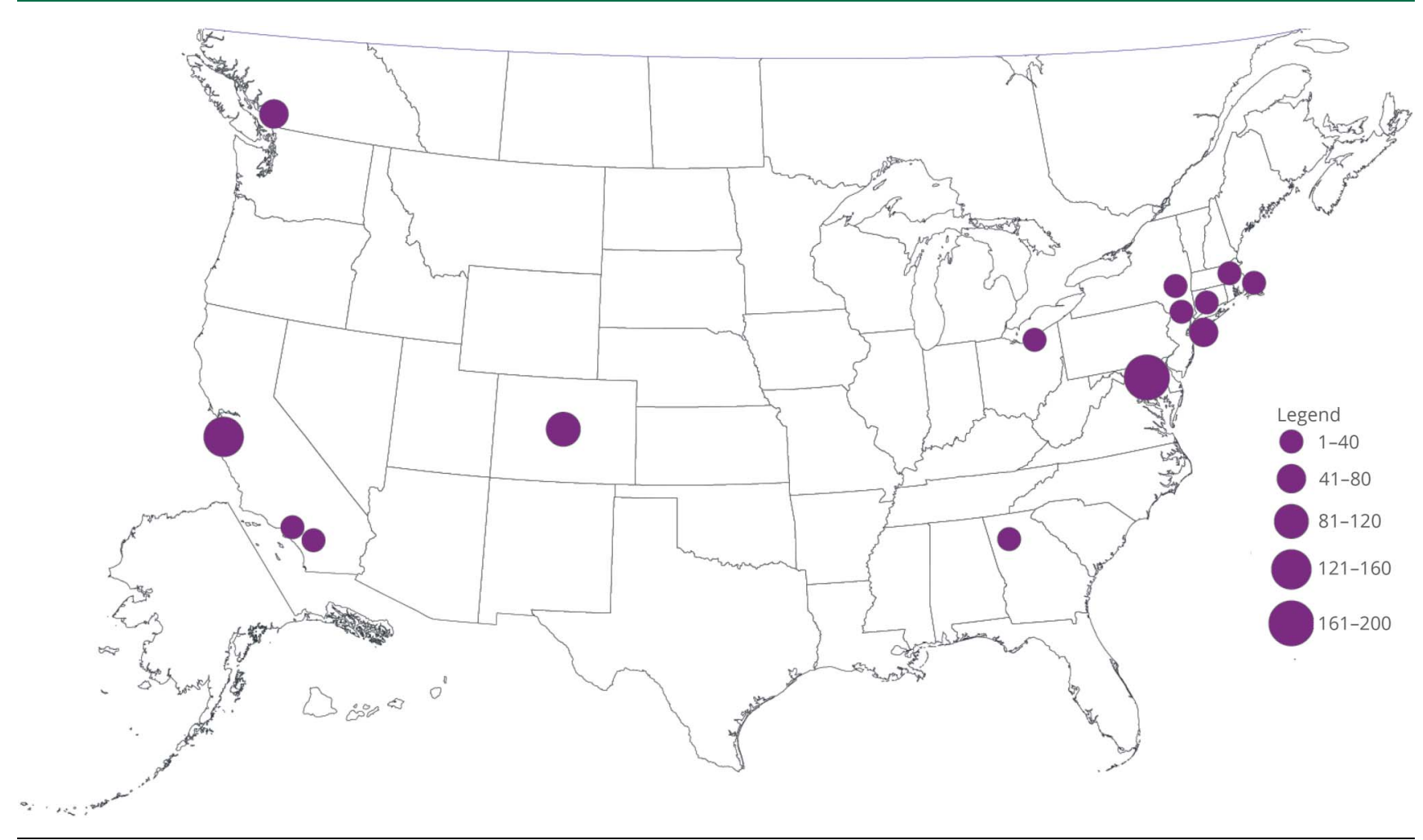

patient cohort and capability to collect data and biospecimens in the protocol-defined manner. Biospecimens, predominantly peripheral blood constituents, are rapidly transferred to a centralized commercial laboratory for processing and archiving.

\section{Cohorts}

The study comprises 3 participant cohorts based on the following inclusion criteria: (1) cases with clinically diagnosed NMOSD according to either the Wingerchuk $2006^{14}$ or International Panel for NMOSD Diagnosis $2015^{14}$ criteria and classified with respect to anti-AQP4 serostatus; (2) comparative disease controls (including CNS autoimmune diseases [e.g., MS]; other autoimmune diseases [e.g., systemic lupus erythematosus, Sjögren syndrome, and type I diabetes mellitus]; chronic nonautoimmune inflammatory or systemic conditions [e.g., cardiovascular disease and type 2 diabetes]); and (3) healthy controls (i.e., those not carrying a chronic disease diagnosis at enrollment). Controls included consanguineous relatives and unrelated individuals (tables 1 and 2). Enrollment is targeted to a 2:1 ratio of cases to controls and is monitored centrally. Individuals (both cases and controls) are excluded if the treating physician feels that they are not appropriate for the study. Control participants are not sex or age matched. Some comparative disease controls are recruited from referral cohorts (e.g., MS). Others are recruited through opportunity or convenience.
Sites are instructed to enroll control participants at a rate of $50 \% \mathrm{MS}$ and $50 \%$ from the other categories.

\section{Intervals}

After enrollment, NMOSD cases are evaluated clinically at 6-month intervals to provide an updated clinical history and complete set of biospecimens. Control participants undergo these same assessments at least annually. The panel of biospecimens routinely collected is listed in supplemental table 1 (links.lww.com/NXI/A121). The protocol allows collection of CSF and additional tissues (e.g., placenta) as available from medically indicated care. Relapses are evaluated regardless of interval and adjudicated by site neurologists.

\section{Participating cohorts}

\section{Eligibility}

Individuals fulfilling inclusion criteria and absent exclusion criteria are eligible for enrollment. Individuals weighing $<17$ $\mathrm{kg}$ are excluded from blood collections but may otherwise participate.

\section{Enrollment}

Clinical research coordinators (CRCs) screen information pertaining to inclusion and exclusion criteria. Individuals receive study information through mail and/or social media and, where institutional review board-approved, have the 
Table 1 Summary of case participant characteristics by serostatus

\begin{tabular}{|c|c|c|c|c|}
\hline & \multirow[b]{2}{*}{ Overall $^{\mathrm{a}}(\mathrm{N}=599)$} & \multicolumn{2}{|l|}{ NMO-IgG status } & \multirow[b]{2}{*}{$p$ Value } \\
\hline & & Negative $(N=139)$ & Positive $(N=449)$ & \\
\hline Female & $504(84.1 \%)$ & $102(73.4 \%)$ & $393(87.5 \%)$ & $<0.001^{\mathrm{g}}$ \\
\hline Participant primary ethnicity/race designation & & & & $<0.001^{\mathrm{g}}$ \\
\hline Asian & $54(9.0 \%)$ & $17(12.2 \%)$ & $37(8.2 \%)$ & \\
\hline Black or African American & $141(23.5 \%)$ & $16(11.5 \%)$ & $125(27.8 \%)$ & \\
\hline Hispanic or Latino & $74(12.4 \%)$ & $13(9.4 \%)$ & $60(13.4 \%)$ & \\
\hline White & $315(52.6 \%)$ & $87(62.6 \%)$ & $218(48.6 \%)$ & \\
\hline Other & $15(2.5 \%)$ & $6(4.3 \%)$ & $9(2.0 \%)$ & \\
\hline Not reported & $0(0 \%)$ & $0(0 \%)$ & $0(0 \%)$ & \\
\hline Age at consent & $47.1(36.0-57.2)$ & $43.3(29.8-52.3)$ & $48.6(37.7-59.1)$ & $<0.001^{\mathrm{h}}$ \\
\hline Age at first episode onset ${ }^{b}$ & $38.4(28.9-50.6)$ & $35.1(25.8-46.4)$ & $39.4(29.9-52.5)$ & $0.002^{h}$ \\
\hline Relapse/year from disease onset to most recent visit ${ }^{c}$ & $0.5(0.3-0.8)$ & $0.5(0.3-0.9)$ & $0.4(0.3-0.8)$ & $0.031^{\mathrm{h}}$ \\
\hline Time (y) from first episode onset to enrollment ${ }^{b}$ & $4.6(1.5-10.1)$ & $3.8(1.4-7.0)$ & $4.9(1.5-11.0)$ & $0.008^{h}$ \\
\hline Longitudinally extensive transverse myelitis ${ }^{d}$ & $396(66.1 \%)$ & $83(59.7 \%)$ & $305(67.9 \%)$ & $0.064^{\mathrm{g}}$ \\
\hline Optic neuritis $^{f}$ & $395(65.9 \%)$ & $102(73.4 \%)$ & $286(63.7 \%)$ & $0.038^{\mathrm{g}}$ \\
\hline Brainstem syndrome $^{f}$ & $155(25.9 \%)$ & $40(28.8 \%)$ & $111(24.7 \%)$ & $0.346^{\mathrm{g}}$ \\
\hline Focal transverse myelitis ${ }^{e}$ & $143(23.9 \%)$ & $46(33.1 \%)$ & $94(20.9 \%)$ & $0.004^{g}$ \\
\hline Area postrema syndrome ${ }^{f}$ & $88(14.7 \%)$ & $20(14.4 \%)$ & $66(14.7 \%)$ & $0.920^{g}$ \\
\hline Cerebral syndrome $^{f}$ & $74(12.4 \%)$ & $20(14.4 \%)$ & $53(11.8 \%)$ & $0.425^{g}$ \\
\hline Diencephalic syndrome $^{f}$ & $23(3.8 \%)$ & $7(5.0 \%)$ & $15(3.3 \%)$ & $0.360^{g}$ \\
\hline
\end{tabular}

Abbreviation: NMO = neuromyelitis optica.

a Eleven case participants have undetermined serostatus.

${ }^{\mathrm{b}}$ Age at first episode onset and time from first episode onset to enrollment not recorded on 6 participants.

c Relapses per year from disease onset to most recent visit not recorded on 32 participants because of insufficient follow-up or missing data.

${ }^{d}$ Longitudinally extensive transverse myelitis not recorded on 3 participants.

e Focal transverse myelitis not recorded on 4 participants.

${ }_{\mathrm{f}}$ Optic neuritis, brainstem syndrome, area postrema syndrome, cerebral syndrome, and diencephalic syndrome not recorded on 2 participants.

${ }^{g} \chi^{2}$ test of association.

${ }^{\mathrm{h}}$ Wilcoxon rank-sum test.

option to provide preliminary information telephonically with consent obtained in advance of study participation. At enrollment, a thorough review of medical records and clinical examination is performed by the study neurologist. A complete disease history and additional relevant study data are collected during the initial interview (table e-3, links.lww.com/NXI/A121). The majority of participants to date have been enrolled coinciding with medically indicated appointments; however, in some cases, enrollment was conducted per protocol at patient-oriented educational events.

\section{Clinical database}

\section{Clinical metadata}

The CIRCLES PSF (table e-2, links.lww.com/NXI/A121) is completed for each participant at enrollment and updated at each follow-up study visit. The PSF data include demographics, disease phenotype, treatment history, and other relevant characteristics. Other than NMOSD disease history, identical clinical data are collected as appropriate from case and healthy control participants.

\section{Data security}

Data are entered into a web-accessible and password-secured electronic data capture system. The CIRCLES study incorporates a query management system that executes nightly. An email notification is generated for each site's CRC identifying any new discrepant data. A weekly reminder email is also provided for remaining discrepant data. The system tracks queries from generation to resolution. Data are curated for quality, consistency, and completeness by the Data Coordinating Center biostatistics group before archiving. Study data are backed up hourly, and a full snapshot of the study is archived nightly. 
Table 2 Summary of control participant characteristics by relatedness to NMOSD cases

\begin{tabular}{|c|c|c|c|}
\hline & Case blood relative $(\mathrm{N}=123)$ & Unrelated $(\mathrm{N}=95)$ & Total $(\mathrm{N}=\mathbf{2 1 8})$ \\
\hline Female & $73(59.3 \%)$ & $71(74.7 \%)$ & $144(66.1 \%)$ \\
\hline \multicolumn{4}{|l|}{ Race $^{\mathbf{a}}$} \\
\hline Asian & $9(7.3 \%)$ & $8(8.4 \%)$ & $17(7.8 \%)$ \\
\hline Black or African American & $8(6.5 \%)$ & $13(13.7 \%)$ & $21(9.6 \%)$ \\
\hline Hispanic or Latino & $20(16.3 \%)$ & $16(16.8 \%)$ & $36(16.5 \%)$ \\
\hline White & $81(65.9 \%)$ & $56(58.9 \%)$ & $137(62.8 \%)$ \\
\hline Other & $4(3.3 \%)$ & $2(2.1 \%)$ & $6(2.8 \%)$ \\
\hline Age at consent $(y)$ & $44.9(34.2-53.9)$ & $50.9(38.9-58.3)$ & $47.1(35.9-56.2)$ \\
\hline \multicolumn{4}{|l|}{ Comparative disease } \\
\hline MS & $37(30.1 \%)$ & $0(0.0 \%)$ & $37(17.0 \%)$ \\
\hline CNS autoimmune disease other than MS & $10(8.1 \%)$ & $0(0.0 \%)$ & $10(4.6 \%)$ \\
\hline Systemic autoimmune disease & $5(4.1 \%)$ & $14(14.7 \%)$ & $19(8.7 \%)$ \\
\hline CNS disorder unrelated to an inflammatory disease & $4(3.3 \%)$ & $1(1.1 \%)$ & $5(2.3 \%)$ \\
\hline Systemic chronic condition & $3(2.4 \%)$ & $4(4.2 \%)$ & $7(3.2 \%)$ \\
\hline None of the above & $69(56.1 \%)$ & $78(82.1 \%)$ & $147(67.4 \%)$ \\
\hline
\end{tabular}

Abbreviation: NMOSD = neuromyelitis optica spectrum disorder.

${ }^{\text {a }}$ Race not recorded on 1 participant.

\section{Biospecimen repository}

\section{Collection, processing, and storage}

Biospecimens are collected according to standard operating procedures at enrollment and follow-up visits. A panel of blood specimens is obtained (table e-1, links.lww.com/NXI/A121) by routine venipuncture by a certified phlebotomist at each scheduled clinical visit. Biospecimens are transported by express courier to a commercial laboratory for processing, systematic labeling, and archiving within 24 hours of collection under certified storage conditions (liquid nitrogen for peripheral blood mononuclear cells and $-80^{\circ} \mathrm{C}$ for sera, plasma, RNA, and DNA).

\section{Quality and serostatus}

Biospecimens are routinely assessed for quality postprocessing and before cryopreservation. Autoantibody serostatus is determined by the respective study site based on reference laboratory assay or review of the case record. For analytical purposes, seropositivity is defined as having detected antiAQP4 at any point during the participant's history.

\section{Statistical analysis}

\section{Analytical range}

The current report encompasses data sets obtained from 2013 through 2017. The CIRCLES study is ongoing.

\section{Analytical methods}

Descriptive statistics (medians or interquartile ranges [IQRs] for numeric variables; counts and percentages for categorical variables) were used to analyze data. Wilcoxon rank-sum tests were used to assess relationships between age at disease onset, annualized relapse rate (ARR) during enrollment in the study, and time between the first and second attacks in relation to other demographic characteristics in NMOSD cases. Relationships between serostatus and race, serostatus and sex, and race and sex were examined using $\chi^{2}$ tests. All analyses were performed in SAS 9.4 (Cary, NC).

\section{Data availability}

Access to data and biospecimens is provided to qualified scholars in a peer-reviewed process. Applications are adjudicated by a biorepository oversight committee elected from among the members of the GJCF International Clinical Consortium (ICC).

\section{Results}

\section{Study enrollment}

As of December 2017, CIRCLES had enrolled 849 NMOSD cases and 339 controls, of which 658 (77.5\%) and 243 (71.7\%), respectively, continue to participate. The percentage of enrollees remaining active has increased over time. Of the 161 participants enrolled in $2013,49.7 \%$ are still active. This compares to $73.7 \%$ of those enrolled in $2014,67.9 \%$ in 2015 , $74.4 \%$ in 2016 , and $90.8 \%$ in 2017 . Inability to contact accounted for most inactivity (74\%), followed by withdraw of consent (14\%), no longer able to participate (9\%), and death (2\%). Of all participants, $60.3 \%, 31.3 \%$, and $8.4 \%$ were enrolled 
at study sites, national patient day events, and regional patient day events, respectively. In-clinic enrollees, compared with national and regional patient day enrollees, were more likely to remain active ( $89.7 \%$ vs $55.1 \%$ and $74.5 \%$, respectively). The size of the enrolled cohort varied among study sites, with the largest site enrolling $286(24.1 \%)$ of all participants and the smallest enrolling 20 (1.7\%). Among active NMOSD cases, 495 (75.2\%) have undergone one or more follow-up visits with biospecimen collection. Among active controls, 129 (53.1\%) had one or more follow-up visits and biospecimen collection. The remainder of the analyses presented are based on these active cases and control participants who have complete data as of the end of the study period.

\section{Cohort demographics and epidemiology}

In the CIRCLES cohort, the female-to-male ratio was 5.3:1 among cases (tables 1 and 2). NMOSD cases self-identified as white/Caucasian (52.6\%), 23.5\% black/African American, 12.4\% Hispanic/Latino, 9.0\% Asian, and 2.5\% from all other races/ethnicities. The overall median age at NMOSD onset was 38.4 years (IQR 28.9-50.6 years), appears to be normally distributed, and spans the range from 2.7 to 79.9 years (figure 2). The median time between disease onset and time to study enrollment was 4.6 years (IQR 1.5-10.1 years). CIRCLES cases experienced an ARR of 0.5 (IQR 0.3-0.9). One hundred thirtytwo cases appear to be monophasic. For cases with $\geq 2$ clinically documented NMOSD relapses $(n=207)$, the median time between the first and second attacks was 0.8 years ( 9 months; IQR 3.3-27.9). The most common relapse manifestations were longitudinally extensive transverse myelitis ( $\geq 2$ vertebral segments; 396, 66.1\%) and optic neuritis (395, 65.9\%). Brainstem syndromes were identified in 155 (25.9\%) cases, 143 (23.9\%) manifested focally confined transverse myelitis, 88 (14.7\%) area postrema syndrome (e.g., prolonged or intractable nausea/ vomiting or hiccups), 74 (12.4\%) cerebral syndrome (cognitive

Figure 2 Age at onset by serostatus and gender

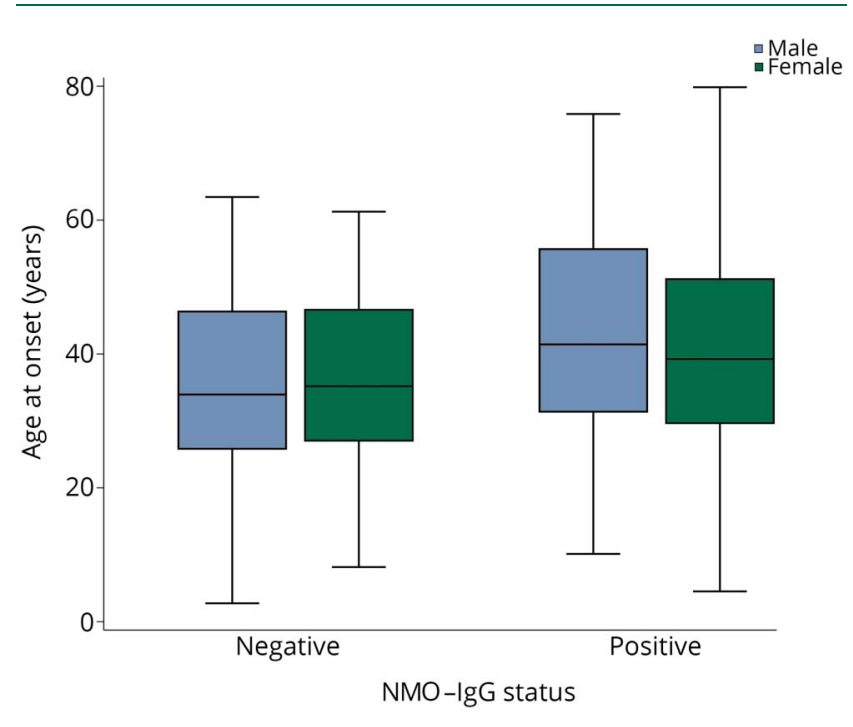

and/or sensory impairment, pain, bowel and/or bladder dysfunction, or limb weakness), and 23 (3.8\%) diencephalic and/or brainstem syndromes (facial numbness, hearing loss, dysphagia, or dysarthria) (table 1).

\section{Biospecimen repertoire}

Of the active NMOSD cases, 193 (32.2\%) provided a single set of biospecimens; 2 longitudinal sets were collected from $151(25.2 \%)$ cases, 3 sets from 107 (17.9\%), and 4 or more from $131(21.9 \%)$. Of the active controls, 102 (46.8\%) provided a single biospecimen set, 65 (29.8\%) 2 sets, 26 (11.9\%) 3 sets, and 21 individuals (9.6\%) have provided 4 or more longitudinal samples.

\section{Correlation analyses}

Bioinformatic analyses have revealed several significant correlates in the CIRCLES cohort (table 1). Anti-AQP4 seropositive cases were more likely to be female $(87.5 \%)$ compared with seronegative cases $(73.4 \%, p<0.001)$. Significant differences in racial distribution by serostatus $(p<$ 0.001 ) were also detected. This result was driven largely by differences in the black/African American and white race categories. Although black/African American participants accounted for only $11.5 \%$ of the seronegative population, they comprise $27.8 \%$ of seropositive cases. Similarly, Hispanic/ Latino cases represent only $9.4 \%$ of seronegative cases, but $13.4 \%$ of seropositive cases. Conversely, white/Caucasian cases account for $62.6 \%$ of seronegative cases, but less than half $(48.6 \%)$ of the seropositive cases. Similarly, Asians account for a higher percentage of the seronegative population $(12.2 \%)$ compared with the seropositive population $(8.2 \%)$.

Overall, seropositive cases are older at initial NMOSD attack compared with seronegative participants (39.4 vs $35.1 ; p=$ 0.002; figure 2). White/Caucasian and Asian cases tend to be older at first attack compared with black/African Americans or Hispanics (41.1 and 38.3 vs 36.5 and 36.0, $p<0.001$; table 3$)$. Seropositive cases tend to have lower ARR than those who are seronegative ( 0.46 vs $0.55 ; p=0.030)$. No significant differences were detected between race and $\operatorname{ARR}(p=0.34)$.

Of the 218 control participants, 95 (43.6\%) are consanguineous with an enrolled case. One hundred forty-four $(66.1 \%)$ are female. The median age of controls at enrollment was 47.1 years. Of the related controls, none have MS, $17.9 \%$ have another autoimmune disease, and $82.1 \%$ have no comparative disease or chronic condition. Of the unrelated controls, $28.5 \%$ have MS, $15.4 \%$ have another autoimmune disease, and $56.1 \%$ have no comparative disease or condition (table 2).

\section{Discussion}

The CIRCLES study represents a unique and multicenter longitudinal observational study, which has successfully recruited and retained a large number of patients affected by the rare disease NMOSD. The substantial number of control participants who are consanguineous with enrolled cases also 
provides important new opportunities to understand disease resilience. In this respect, individuals with familial genotypes and environmental exposures, but who do not manifest NMOSD, can be evaluated in relation to patients with NMOSD. In addition, the CIRCLES project reflects the collaborative input of the GJCF-ICC, a global network of scientific and medical experts in NMOSD.

The demographic characteristics of the CIRCLES cohort to date are comparable to those of previously described NMOSD registries. ${ }^{13,15-22}$ Interesting relationships have emerged from initial demographic, epidemiologic, and correlational analyses of this cohort. Key relationships include identification of correlations between disease attributes and sex, age, and race. NMOSD cases are predominantly female (5.3:1) and anti-AQP4 seropositive (76.4\%). Disease onset most commonly occurs in the fourth decade of life. These findings are congruent with recent epidemiologic studies of NMOSD regarding sex predominance, age at onset, and disease clustering in individuals and their first-degree relatives. ${ }^{5,23-25}$

Analysis of the CIRCLES cohort supports the concept that a sizable proportion of cases satisfying either 2006 or 2015 diagnostic criteria for $\mathrm{NMOSD}^{14,26}$ includes individuals in whom anti-AQP4 is not detected. Approximately $20.6 \%$ of female and $39.8 \%$ of male cases in CIRCLES are anti-AQP4 seronegative, representing a significant difference based on sex $(p<0.001)$. Whether such proportions accurately reflect anti-AQP4 serostatus worldwide, correlate with specific disease phenotypes, or inform regarding response to therapy remains uncertain. Key among the proximate determinants of this serostatus are anti-AQP4 assay sensitivities and specificities. For example, it is possible that therapies inadvertently affect selection bias (e.g., rituximab targeting B cells). However, no consistent evidence published to date has proven these therapies alter antibody detection in Clinical Laboratory Improvement Amendments-approved assays. Seropositive cases are more likely to be female, and self-identified black/ African American or Hispanic/Latino patients are more likely to be anti-AQP4 seropositive, congruent with earlier reports. ${ }^{5}$
Furthermore, cases in which anti-AQP4 is detected are older at first attack than those who are seronegative (39.4 vs 35.1, respectively, $p=0.002$ ). Although white/Caucasian cases accounted for nearly $63 \%$ of the anti-AQP4 seronegative cohort, they account for less than $50 \%$ of seropositive cases. The age at first attack also differed by race, with a nearly 5-year disparity between the median age at onset for Hispanics/ Latinos compared with white/Caucasians. This finding could reflect socioeconomic skewing of access to specialized medical care, a difference in disease activity/severity, other factor(s), or a combination of factors.

Of note, the prevalence of NMOSD appears to differ in distinct geographic regions. For example, the current estimate of NMOSD prevalence is 3.9 per 100,000 in Olmsted County, Minnesota (USA), ${ }^{5}$ similar to that reported in Denmark $\left(4\right.$ per $\left.100,000^{27}\right)$. In contrast, the prevalence ranges from 0.72 per 100,000 in England, ${ }^{28} 0.89$ per 100,000 in Spain, ${ }^{7}$ and 0.9 per 100,000 in Japan $^{6}$ to 1.96 per 100,000 in Wales, ${ }^{29}$ 2.5 per 100,000 in the French West Indies, ${ }^{30} 2.6$ per 100,000 in India, ${ }^{31}$ and as high as 10 per 100,000 in Martinique. ${ }^{5}$ It is possible that differences in diagnostic criteria could underlie at least some of these apparent differences. In any event, the current CIRCLES data offer insights extending those provided by recent reviews. ${ }^{8,32}$

The sizable proportion of cases in which anti-AQP4 is not detected suggests that the NMOSD phenotype can result from multiple, independent immunologic events. The emerging recognition of individuals with phenotypes resembling NMOSD, but in whom anti-myelin oligodendrocyte glycoprotein (anti-MOG) autoantibodies are detected in the absence of anti-AQP4 ${ }^{10,33,34}$ suggests at least 2 intriguing possibilities: (1) a broader array of autoantigens than traditionally appreciated may contribute to astrocytopathies and/ or (2) patients having anti-MOG autoantibodies may reflect a disease entity that is immunologically distinct from NMOSD, despite largely superimposable clinical manifestations. Thus, patients with anti-MOG antibodies may exhibit disease features that are pathogenically distinct from NMOSD, despite their similar clinical presentations. ${ }^{34,35}$

Table 3 Case demographic factors by race and ethnicity

\begin{tabular}{lllll}
\hline & $\mathbf{N}$ & Female $(\mathbf{N}=\mathbf{5 9 9})$ & Age at onset $(\mathbf{N}=\mathbf{5 9 3})$ & ARR (N = 593) \\
\hline White & 315 & $253(80.3 \%)$ & $41.1(31.1-53.0)$ & $0.5(0.3-0.9)$ \\
\hline Black or African American & 141 & $130(92.2 \%)$ & $36.5(26.1-45.5)$ & $0.5(0.3-0.9)$ \\
\hline Hispanic or Latino & 74 & $67(90.5 \%)$ & $36.0(22.6-46.5)$ & $0.5(0.3-1.0)$ \\
\hline Asian & 54 & $43(79.6 \%)$ & $38.3(25.2-50.2)$ & $0.4(0.2-0.7)$ \\
\hline $\begin{array}{l}\text { Other } \\
\boldsymbol{p} \text { Value }\end{array}$ & 15 & $11(73.3 \%)$ & $31.7(22.2-43.1)$ & $0.5(0.2-0.9)$ \\
\hline
\end{tabular}

Abbreviation: $A R R=$ annualized relapse rate

${ }^{\mathrm{a}} \chi^{2}$ test of association.

${ }^{b}$ Analysis of variance. 
Nevertheless, 1 recent epidemiologic study showed that individuals with detectable anti-MOG antibody had similar disease prevalence and long-term prognosis when compared with patients lacking detectable anti-AQP4 or anti-MOG antibody. ${ }^{10}$ Thus, the relationship between serology and disease phenotype remains to be more clearly understood.

As with all large, multicenter clinical research studies, there are limitations to CIRCLES. Some participants inconsistently followed up or provided incomplete historical information. Complete acquisition of PSF data elements, biospecimens, and fully documented neurologic examination data has proven challenging. In turn, acquiring disability data from incomplete neurologic examinations has emerged as a high priority for improvement. For example, although $90.9 \%$ of examinations included completed motor function assessments, only $49.5 \%$ assessed visual acuity, and $8.7 \%$ completed the Expanded Disability Status Scale. The study has not systematically monitored anti-MOG serostatus, ${ }^{16}$ as no approved clinical assay for this autoantibody existed during the study period.

A unique aspect of CIRCLES concerns the detailed clinical history captured at enrollment. For those whose disease is of long duration, recall bias is possible. Beyond basic clinical data, the CIRCLES PSF requests extensive retrospective clinical information, including history of infectious diseases, vaccinations, familial autoimmune diseases, medications, and treatments. Although collection of such extensive information is labor intensive, the resulting data set enables interrogations not possible from smaller or less comprehensive databases. Opportunities for enhancing study performance are currently being addressed through refinements of the study protocol. In particular, increased emphasis has been placed on longitudinal participation, more frequent site monitoring, and systematic methods for disseminating information to study sites pertaining to study performance and efficiency.

The design of CIRCLES allows direct comparisons between the clinical courses of NMOSD and other autoimmune diseases, informing key immunologic events unique to NMOSD. These events in turn facilitate identification of clinically useful biomarkers, including those heralding disease relapse, as well as novel therapeutic targets, agents, and strategies. The CIRCLES biobank contains clinical information and biospecimens from ethnically and geographically diverse cases, including those with heterotypic phenotypes. Thus, CIRCLES represents a unique resource to the academic and drug-discovery communities focused on finding solutions for patients with NMOSD and may enhance parallel efforts in other immune-based diseases.

In summary, areas of research urgently needed in NMOSD include discovery of disease etiology, identification of risk factors, and identification of biomarkers reflecting disease activity and predicting relapse. ${ }^{36,37}$ The ongoing CIRCLES continues to enroll and follow cases and categorical control participants in a systematic and longitudinal manner. This effort is intended to facilitate breakthroughs regarding the epidemiology and pathogenesis of NMOSD, to reduce barriers to performing well-designed therapeutic trials, and to support postapproval studies of eventually approved therapeutics. Thus, the overarching goal of CIRCLES is to improve patient quality of life through improved diagnosis, relapse prevention, and eventual cures. ${ }^{38-40}$

The CIRCLES program enables unprecedented opportunities to accelerate breakthroughs in scientific understanding and clinical solutions for NMOSD. Key to the future applicability of CIRCLES will be increased precision in diagnosis and uniformity in the assessment and specification of distinct disease phenotypes. These advances hinge on greater consistency of serologic analysis regarding autoantibodies specific to disease phenotype and standardization in the definition and severity scoring of NMOSD relapses. As these advances are made, they will be incorporated into the definitions used by CIRCLES, attesting to the evolving nature of this research platform. CIRCLES remains an open resource to facilitate hypothesis generation and testing. Given the nature of the biospecimens being collected, CIRCLES enables studies ranging from genomics, transcriptomics, proteomics, and other molecularand cellular-based research, in addition to clinical investigation.

\section{Acknowledgment}

The authors recognize the efforts of the following individuals: Yanet Babcock, Alexandra Kocsik, J. Michael Dean, Colleen Farrell, Haojun Feng, Susan Filomena, Toni Ganaway, Samuel Glaisher, Rivka Green, Elizabeth Gonzales, Elaine Hsu, Catherine J. Johnson, Marlene Keymolen Ramirez, Gloria Rodriguez, Angela Stangorone, Ben W. Thrower, and Gabriella Tosto. The CIRCLES project team, including site PIs and coordinators, the DCC team, and The GJCF and its advisors are grateful to study participants, caregivers, and families who participated in this study. The CIRCLES project is supported by The Guthy-Jackson Charitable Foundation.

\section{Study funding}

The CIRCLES project is supported by The Guthy-Jackson Charitable Foundation.

\section{Disclosure}

L.J. Cook is supported in part by The Guthy-Jackson Charitable Foundation, which is a sponsor of this research. J.W. Rose is supported in part by The Guthy-Jackson Charitable Foundation, which is a sponsor of this research; he receives research funding from the National Multiple Sclerosis Society, Biogen, and NIH. J.S. Alvey, A.M. Jolley, R. Kuhn, B. Marron, M. Pederson, R. Enriquez, J. Yearley, and S. McKechnie are supported in part by The Guthy-Jackson Charitable Foundation, which is a sponsor of this research. M.H. Han served on the advisory committee of Novartis; received travel funding and/or speaker honoraria from the University of California, San Diego, and CMSC; consulted for Sanofi Genzyme; and received research support from The GuthyJackson Charitable Foundation and The Leducq Foundation. 
A.J. Tomczak is supported in part by The Guthy-Jackson Charitable Foundation, which is a sponsor of this research. M. Levy is on the scientific advisory boards of Asterias, Chugai, and Alexion; is on the editorial board of Multiple Sclerosis and Related Disorders; holds a patent for aquaporin-4 sequence that elicits pathogenic $\mathrm{T}$ cell response in animal model of neuromyelitis optica; has consulted for Guidepoint Global, Gerson-Lehrman Group, and Cowen Group; and received research support from Viropharma/Shire, Acorda, ApoPharma, Sanofi, Genzyme, Alnylam, Alexion, Terumo BCT, NIH/NINDS, and The Guthy-Jackson Charitable Foundation. M.A. Mealy and J. Coleman are supported in part by The Guthy-Jackson Charitable Foundation, which is a sponsor of this research. J.L. Bennett is on the editorial boards of the Journal of Neuro-ophthalmology, Multiple Sclerosis, and Neurology: Neuroimmunology \& Neuroinflammation; holds a patent for compositions and methods for the treatment of neuromyelitis optica; has consulted for AbbVie, EMD Serono, Mallinckrodt Pharmaceuticals, Equillium, MedImmune, Chugai, Frequency Therapeutics, Genentech, Genzyme, and Clene Nanomedicine; and received research support from EMD Serono, Mallinckrodt, NIH, and The Guthy-Jackson Charitable Foundation. R. Johnson and M. Barnes-Garcia are supported in part by The Guthy-Jackson Charitable Foundation, which is a sponsor of this research. A.L. Traboulsee has the following competing financial interests: research funding from Biogen, Chugai, Novartis, Roche, and Sanofi Genzyme; consultancy honoraria from Biogen, Roche, Sanofi Genzyme, and Teva Neuroscience; and supported in part by The GuthyJackson Charitable Foundation, which is a sponsor of this research. R.L. Carruthers is Site Investigator for studies funded by Roche, Novartis, MedImmune, and EMD Serono; receives research support from Teva Innovation Canada, Roche Canada, Vancouver Coastal Health Research Institute; and is supported in part by The Guthy-Jackson Charitable Foundation, which is a sponsor of this research. R.L. Carruthers has received honoraria from Roche, EMD Serono, Sanofi, Biogen, Novartis, and Teva. L.E. Lee, J.L. Schubert, and $\mathrm{K}$. McMullen were supported in part by The GuthyJackson Charitable Foundation, which is a sponsor of this research. I. Kister served on the scientific advisory boards of Biogen and Genentech and received research support from The Guthy-Jackson Charitable Foundation, National Multiple Sclerosis Society, Biogen, EMD Serono, Genentech, Genzyme, and Novartis. Z Rimler and A. Reid are supported in part by The Guthy-Jackson Charitable Foundation, which is a sponsor of this research. N.L. Sicotte is supported in part by the National Multiple Sclerosis Society, the PatientCentered Outcomes Research Institute (PCORI), and The Guthy-Jackson Charitable Foundation, which is a sponsor of this research. S.M. Planchon is supported in part by The Guthy-Jackson Charitable Foundation, which is a sponsor of this research. J.A. Cohen reports personal compensation for consulting for Alkermes, Biogen, Convelo, EMD Serono, ERT, Gossamer Bio, Novartis, and ProValuate, speaking for Mylan and Synthon, and serving as an editor of Multiple Sclerosis Journal, and was supported in part by The Guthy-
Jackson Charitable Foundation, which is a sponsor of this research. D. Ivancic and J.L. Sedlak are supported in part by The Guthy-Jackson Charitable Foundation, which is a sponsor of this research. I.K. Sand receives research support from United States Department of Defense, the National Multiple Sclerosis Society, and The Guthy-Jackson Charitable Foundation. P. Repovic received travel funding and/or honoraria from Biogen, EMD Serono, Genzyme, and Genentech, consulting fees from Biogen, Novartis, Genentech, and EMD Serono, and research support from Genentech, National Multiple Sclerosis Society, and Consortium of MS Centers, and was supported in part by The Guthy-Jackson Charitable Foundation, which is a sponsor of this research. L. Amezcua has received personal compensation for consulting, serving on a scientific advisory board, speaking, or other activities with Genzyme. She receives research funding from Biogen, MedDay, NMSS, NIH NINDS, California Community Foundation, and The Guthy-Jackson Charitable Foundation. A. Pruitt and E. Amundson are supported in part by The GuthyJackson Charitable Foundation, which is a sponsor of this research. T. Chitnis served on the clinical advisory boards of Novartis, Celgene, and Sanofi Genzyme; consulted for Biogen, Celgene, Novartis, and Sanofi Genzyme; received research support from Merck Serono, Verily, NIH, MNSS, Peabody Foundation, and Consortium for MS Centers; and was supported in part by The Guthy-Jackson Charitable Foundation, which is a sponsor of the research. D.S. Mullin is supported in part by The Guthy-Jackson Charitable Foundation, which is a sponsor of this research. E.C. Klawiter has received consulting fees from Acorda Therapeutics, Atlas5d, Biogen Idec, EMD Serono, Genentech, and Shire and research support from Atlas5d, Biogen Idec, EMD Serono, and Roche and was supported in part by The Guthy-Jackson Charitable Foundation, which is a sponsor of this research. A.W. Russo is supported in part by The Guthy-Jackson Charitable Foundation, which is a sponsor of this research. C.S. Riley has participated in advisory boards and received honoraria from Novartis, Biogen Idec, Teva, Genentech, Roche, and Genzyme and was supported in part by The Guthy-Jackson Charitable Foundation, which is a sponsor of this research. K.B. Onomichi, L. Levine, K.E. Nelson, N.M. Nealon, and C. Engel are supported in part by The GuthyJackson Charitable Foundation, which is a sponsor of this research. M. Kruse-Hoyer reports no disclosures. M. Marcille, L. Tornes, A. Rumpf, A. Greer, M. Kenneally Behne, R.R. Rodriguez, D.W. Behne, D.W. Blackway, and B. Coords are supported in part by The Guthy-Jackson Charitable Foundation, which is a sponsor of this research. T.F. Blaschke is an advisor to The Guthy-Jackson Charitable Foundation, which is a sponsor of this research. J. Sheard is supported in part by The Guthy-Jackson Charitable Foundation, which is a sponsor of this research. T.J. Smith is an advisor to The Guthy-Jackson Charitable Foundation, which is a sponsor of this research. J.M. Behne is supported in part by The Guthy-Jackson Charitable Foundation, which is a sponsor of this research. M.R. Yeaman is supported by research funding from the National Institutes of Health; U.S. Department of Defense; is Founder and 
Appendix 1 (continued)

\begin{tabular}{|c|c|c|c|c|c|c|c|}
\hline Name & Location & Role & Contribution & Name & Location & Role & Contribution \\
\hline $\begin{array}{l}\text { Anthony L. } \\
\text { Traboulsee, } \\
\text { MD }\end{array}$ & $\begin{array}{l}\text { Department of } \\
\text { Medicine \& } \\
\text { Neurology, University } \\
\text { of British Columbia, } \\
\text { Vancouver, BC, } \\
\text { Canada }\end{array}$ & Author & $\begin{array}{l}\text { Participated in study } \\
\text { design; performed } \\
\text { clinical assessments; } \\
\text { collected study data } \\
\text { and biospecimens; } \\
\text { and reviewed the } \\
\text { manuscript for } \\
\text { intellectual content. }\end{array}$ & $\begin{array}{l}\text { Jeffery A. } \\
\text { Cohen, MD }\end{array}$ & $\begin{array}{l}\text { Mellen Center for MS } \\
\text { Treatment and } \\
\text { Research, } \\
\text { Neurological } \\
\text { Institute, Cleveland } \\
\text { Clinic, Cleveland, OH }\end{array}$ & Author & $\begin{array}{l}\text { Performed clinical } \\
\text { assessments; } \\
\text { collected study data } \\
\text { and biospecimens; } \\
\text { and reviewed and } \\
\text { revised the } \\
\text { manuscript for } \\
\text { intellectual content. }\end{array}$ \\
\hline $\begin{array}{l}\text { Robert L. } \\
\text { Carruthers, } \\
\text { MD }\end{array}$ & $\begin{array}{l}\text { Department of } \\
\text { Medicine \& } \\
\text { Neurology, University } \\
\text { of British Columbia, } \\
\text { Vancouver, BC, } \\
\text { Canada }\end{array}$ & Author & $\begin{array}{l}\text { Participated in study } \\
\text { design; performed } \\
\text { clinical assessments; } \\
\text { collected study data } \\
\text { and biospecimens; } \\
\text { and reviewed the } \\
\text { manuscript for } \\
\text { intellectual content. }\end{array}$ & $\begin{array}{l}\text { Diane } \\
\text { Ivancic, } \\
\text { CCRP }\end{array}$ & $\begin{array}{l}\text { Mellen Center for MS } \\
\text { Treatment and } \\
\text { Research, } \\
\text { Neurological } \\
\text { Institute, Cleveland } \\
\text { Clinic, Cleveland, OH }\end{array}$ & Author & $\begin{array}{l}\text { Collected study data } \\
\text { and reviewed the } \\
\text { manuscript for } \\
\text { intellectual content. }\end{array}$ \\
\hline \multirow[t]{2}{*}{$\begin{array}{l}\text { Lisa } \\
\text { Eunyoung } \\
\text { Lee, BS, MSc }\end{array}$} & \multirow{2}{*}{$\begin{array}{l}\text { Department of } \\
\text { Medicine \& } \\
\text { Neurology, University } \\
\text { of British Columbia, } \\
\text { Vancouver, BC, } \\
\text { Canada }\end{array}$} & \multirow[t]{2}{*}{ Author } & \multirow{2}{*}{$\begin{array}{l}\text { Participated in study } \\
\text { design; collected } \\
\text { study data; analyzed } \\
\text { and interpreted the } \\
\text { data; and reviewed/ } \\
\text { revised the } \\
\text { manuscript for } \\
\text { intellectual content. }\end{array}$} & $\begin{array}{l}\text { Jennifer L. } \\
\text { Sedlak, BSN }\end{array}$ & $\begin{array}{l}\text { Mellen Center for MS } \\
\text { Treatment and } \\
\text { Research, } \\
\text { Neurological } \\
\text { Institute, Cleveland } \\
\text { Clinic, Cleveland, OH }\end{array}$ & Author & $\begin{array}{l}\text { Collected study data } \\
\text { and reviewed the } \\
\text { manuscript for } \\
\text { intellectual content. }\end{array}$ \\
\hline & & & & $\begin{array}{l}\text { Ilana Katz } \\
\text { Sand, MD }\end{array}$ & $\begin{array}{l}\text { Icahn School of } \\
\text { Medicine at Mount } \\
\text { Sinai, NY }\end{array}$ & Author & $\begin{array}{l}\text { Participated in study } \\
\text { design; performed } \\
\text { clinical assessments; } \\
\text { collected study data }\end{array}$ \\
\hline \multirow[t]{2}{*}{$\begin{array}{l}\text { Julia J. } \\
\text { Schubert, } \\
\text { BS, BCS }\end{array}$} & \multirow{2}{*}{$\begin{array}{l}\text { Department of } \\
\text { Medicine \& } \\
\text { Neurology, University } \\
\text { of British Columbia, } \\
\text { Vancouver, BC, } \\
\text { Canada }\end{array}$} & \multirow[t]{2}{*}{ Author } & \multirow[t]{2}{*}{$\begin{array}{l}\text { Collected study data } \\
\text { and reviewed the } \\
\text { manuscript for } \\
\text { intellectual content. }\end{array}$} & & & & $\begin{array}{l}\text { and biospecimens; } \\
\text { and reviewed and } \\
\text { revised the manuscript } \\
\text { for intellectual content. }\end{array}$ \\
\hline & & & & Pavle & Multiple Sclerosis & Author & Participated in study \\
\hline \multirow[t]{2}{*}{$\begin{array}{l}\text { Katrina } \\
\text { McMullen, } \\
\text { PhD }\end{array}$} & \multirow{2}{*}{$\begin{array}{l}\text { Department of } \\
\text { Medicine \& } \\
\text { Neurology, University } \\
\text { of British Columbia, } \\
\text { Vancouver, BC, } \\
\text { Canada }\end{array}$} & \multirow[t]{2}{*}{ Author } & \multirow[t]{2}{*}{$\begin{array}{l}\text { Collected study data } \\
\text { and reviewed the } \\
\text { manuscript for } \\
\text { intellectual content. }\end{array}$} & MD, PhD & $\begin{array}{l}\text { Neuroscience } \\
\text { Institute, Seattle, WA }\end{array}$ & & $\begin{array}{l}\text { and revised the } \\
\text { manuscript for } \\
\text { intellectual content. }\end{array}$ \\
\hline & & & & $\begin{array}{l}\text { Lilyana } \\
\text { Amezcua, } \\
\text { MD MS }\end{array}$ & $\begin{array}{l}\text { Department of } \\
\text { Neurology, Keck } \\
\text { School of Medicine }\end{array}$ & Author & $\begin{array}{l}\text { Participated in study } \\
\text { design; performed } \\
\text { clinical assessments; }\end{array}$ \\
\hline \multirow[t]{2}{*}{$\begin{array}{l}\text { Ilya Kister, } \\
\text { MD }\end{array}$} & \multirow[t]{2}{*}{$\begin{array}{l}\text { NYU Langone Health, } \\
\text { New York, NY }\end{array}$} & \multirow[t]{2}{*}{ Author } & \multirow{2}{*}{$\begin{array}{l}\text { Participated in study } \\
\text { design; performed } \\
\text { clinical assessments; } \\
\text { collected study data } \\
\text { and biospecimens; } \\
\text { and reviewed and } \\
\text { revised the manuscript } \\
\text { for intellectual content. }\end{array}$} & & $\begin{array}{l}\text { University of } \\
\text { Southern California, } \\
\text { Los Angeles, CA }\end{array}$ & & $\begin{array}{l}\text { collected study data } \\
\text { and biospecimens; and } \\
\text { reviewed and revised } \\
\text { the manuscript for } \\
\text { intellectual content. }\end{array}$ \\
\hline & & & & $\begin{array}{l}\text { Ana Pruitt, } \\
\text { BS }\end{array}$ & $\begin{array}{l}\text { Department of } \\
\text { Neurology, Keck } \\
\text { School of Medicine, }\end{array}$ & Author & $\begin{array}{l}\text { Collected study data } \\
\text { and reviewed the } \\
\text { manuscript for }\end{array}$ \\
\hline $\begin{array}{l}\text { Zoe Rimler, } \\
\text { BS }\end{array}$ & $\begin{array}{l}\text { NYU Langone Health, } \\
\text { New York, NY }\end{array}$ & Author & $\begin{array}{l}\text { Collected study data } \\
\text { and reviewed the } \\
\text { manuscript for } \\
\text { intellectual content. }\end{array}$ & & $\begin{array}{l}\text { University of } \\
\text { Southern California, } \\
\text { Los Angeles, CA }\end{array}$ & & intellectual content. \\
\hline $\begin{array}{l}\text { Allyson } \\
\text { Reid, BA }\end{array}$ & $\begin{array}{l}\text { NYU Langone Health, } \\
\text { New York, NY }\end{array}$ & Author & $\begin{array}{l}\text { Collected study data } \\
\text { and reviewed the } \\
\text { manuscript for } \\
\text { intellectual content. }\end{array}$ & $\begin{array}{l}\text { Erika } \\
\text { Amundson, } \\
\text { BA }\end{array}$ & $\begin{array}{l}\text { Department of } \\
\text { Neurology, Keck } \\
\text { School of Medicine, } \\
\text { University of } \\
\text { Southern California, } \\
\text { Los Angeles, CA }\end{array}$ & & $\begin{array}{l}\text { Collected study data } \\
\text { and reviewed the } \\
\text { manuscript for } \\
\text { intellectual content. }\end{array}$ \\
\hline $\begin{array}{l}\text { Nancy L. } \\
\text { Sicotte, MD }\end{array}$ & $\begin{array}{l}\text { Department of } \\
\text { Neurology, Cedars- } \\
\text { Sinai Medical Center, } \\
\text { Los Angeles, CA }\end{array}$ & Author & $\begin{array}{l}\text { Performed clinical } \\
\text { assessments; collected } \\
\text { study data and } \\
\text { biospecimens; and } \\
\text { reviewed and revised } \\
\text { the manuscript for } \\
\text { intellectual content. }\end{array}$ & $\begin{array}{l}\text { Tanuja } \\
\text { Chitnis, MD }\end{array}$ & $\begin{array}{l}\text { Department of } \\
\text { Neurology, Brigham } \\
\text { and Women's } \\
\text { Hospital, Harvard } \\
\text { Medical School, } \\
\text { Boston, MA }\end{array}$ & Author & $\begin{array}{l}\text { Participated in study } \\
\text { design; performed } \\
\text { clinical assessments; } \\
\text { collected study data } \\
\text { and biospecimens; } \\
\text { and reviewed and } \\
\text { revised the manuscript }\end{array}$ \\
\hline \multirow{2}{*}{$\begin{array}{l}\text { Sarah M. } \\
\text { Planchon, } \\
\text { PhD }\end{array}$} & \multirow{2}{*}{$\begin{array}{l}\text { Mellen Center for MS } \\
\text { Treatment and } \\
\text { Research, } \\
\text { Neurological } \\
\text { Institute, Cleveland } \\
\text { Clinic, Cleveland, OH }\end{array}$} & \multirow[t]{2}{*}{ Author } & \multirow{2}{*}{$\begin{array}{l}\text { Participated in study } \\
\text { design; collected } \\
\text { study data and } \\
\text { biospecimens; and } \\
\text { reviewed and revised } \\
\text { the manuscript for } \\
\text { intellectual content. }\end{array}$} & & & & for intellectual content. \\
\hline & & & & $\begin{array}{l}\text { Devin S. } \\
\text { Mullin, BS }\end{array}$ & $\begin{array}{l}\text { Department of } \\
\text { Neurology, Brigham } \\
\text { and Women's Hospital, } \\
\text { Harvard Medical } \\
\text { School, Boston, MA }\end{array}$ & Author & $\begin{array}{l}\text { Collected study data } \\
\text { and reviewed the } \\
\text { manuscript for } \\
\text { intellectual content. }\end{array}$ \\
\hline
\end{tabular}

Appendix 1 (continued)

Research,

Neurological

Institute, Cleveland

manuscript for

Collected study data

Research,

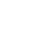


Appendix 1 (continued)

\begin{tabular}{|c|c|c|c|}
\hline Name & Location & Role & Contribution \\
\hline $\begin{array}{l}\text { Eric C. } \\
\text { Klawiter, } \\
\text { MD }\end{array}$ & $\begin{array}{l}\text { Department of } \\
\text { Neurology, } \\
\text { Massachusetts } \\
\text { General Hospital, } \\
\text { Harvard Medical } \\
\text { School, Boston, MA }\end{array}$ & Author & $\begin{array}{l}\text { Participated in study } \\
\text { design; performed } \\
\text { clinical assessments; } \\
\text { collected study data } \\
\text { and biospecimens; } \\
\text { and reviewed and } \\
\text { revised the } \\
\text { manuscript for } \\
\text { intellectual content. }\end{array}$ \\
\hline
\end{tabular}

\begin{tabular}{|c|c|c|c|}
\hline $\begin{array}{l}\text { Andrew W. } \\
\text { Russo, BS }\end{array}$ & $\begin{array}{l}\text { Department of } \\
\text { Neurology, } \\
\text { Massachusetts } \\
\text { General Hospital, } \\
\text { Harvard Medical } \\
\text { School, Boston, MA }\end{array}$ & Author & $\begin{array}{l}\text { Collected study data } \\
\text { and reviewed the } \\
\text { manuscript for } \\
\text { intellectual content. }\end{array}$ \\
\hline
\end{tabular}

Claire S. Department of Author Participated in study

Riley, MD Neurology, Columbia design; performed

University Medical clinical assessments;

Center, New York, NY collected study data

and biospecimens

and reviewed and

revised the

manuscript for

intellectual content.

\begin{tabular}{|c|c|c|c|}
\hline $\begin{array}{l}\text { Kaho B. } \\
\text { Onomichi, } \\
\text { MS }\end{array}$ & $\begin{array}{l}\text { Department of } \\
\text { Neurology, Columbia } \\
\text { University Medical } \\
\text { Center, New York, NY }\end{array}$ & Author & $\begin{array}{l}\text { Collected study data } \\
\text { and reviewed the } \\
\text { manuscript for } \\
\text { intellectual content. }\end{array}$ \\
\hline $\begin{array}{l}\text { Libby } \\
\text { Levine, RN, } \\
\text { ANP-BC }\end{array}$ & $\begin{array}{l}\text { Department of } \\
\text { Neurology, Columbia } \\
\text { University Medical } \\
\text { Center, NY, NY }\end{array}$ & Author & $\begin{array}{l}\text { Collected study data } \\
\text { and reviewed the } \\
\text { manuscript for } \\
\text { intellectual content. }\end{array}$ \\
\hline $\begin{array}{l}\text { Katherine E. } \\
\text { Nelson, BA }\end{array}$ & $\begin{array}{l}\text { Department of } \\
\text { Neurology, Columbia } \\
\text { University Medical } \\
\text { Center, NY, NY }\end{array}$ & Author & $\begin{array}{l}\text { Collected study data } \\
\text { and reviewed the } \\
\text { manuscript for } \\
\text { intellectual content. }\end{array}$ \\
\hline $\begin{array}{l}\text { Nancy M. } \\
\text { Nealon, MD }\end{array}$ & $\begin{array}{l}\text { Weill Cornell } \\
\text { Medicine, New York, } \\
\text { NY }\end{array}$ & Author & $\begin{array}{l}\text { Participated in study } \\
\text { design; performed } \\
\text { clinical assessments; } \\
\text { collected study data } \\
\text { and biospecimens; } \\
\text { and reviewed and } \\
\text { revised the } \\
\text { manuscript for } \\
\text { intellectual content. }\end{array}$ \\
\hline $\begin{array}{l}\text { Casey Engel, } \\
\text { BA }\end{array}$ & $\begin{array}{l}\text { Weill Cornell } \\
\text { Medicine, New York, } \\
\text { NY }\end{array}$ & Author & $\begin{array}{l}\text { Collected study data } \\
\text { and reviewed the } \\
\text { manuscript for } \\
\text { intellectual content. }\end{array}$ \\
\hline $\begin{array}{l}\text { Mason } \\
\text { Kruse- } \\
\text { Hoyer, MD, } \\
\text { MA }\end{array}$ & $\begin{array}{l}\text { Weill Cornell } \\
\text { Medicine, New York, } \\
\text { NY }\end{array}$ & Author & $\begin{array}{l}\text { Collected study data } \\
\text { and reviewed the } \\
\text { manuscript for } \\
\text { intellectual content. }\end{array}$ \\
\hline $\begin{array}{l}\text { Melanie } \\
\text { Marcille, BA }\end{array}$ & $\begin{array}{l}\text { Weill Cornell } \\
\text { Medicine, New York, } \\
\text { NY }\end{array}$ & Author & $\begin{array}{l}\text { Collected study data } \\
\text { and reviewed the } \\
\text { manuscript for } \\
\text { intellectual content. }\end{array}$ \\
\hline $\begin{array}{l}\text { Leticia } \\
\text { Tornes, MD }\end{array}$ & $\begin{array}{l}\text { Department of } \\
\text { Neurology, Division of } \\
\text { Multiple Sclerosis, } \\
\text { University of Miami } \\
\text { Miller School of } \\
\text { Medicine, Miami, FL }\end{array}$ & Author & $\begin{array}{l}\text { Participated in study } \\
\text { design; performed } \\
\text { clinical assessments; } \\
\text { collected study data } \\
\text { and biospecimens; } \\
\text { and reviewed and } \\
\text { revised the } \\
\text { manuscript for } \\
\text { intellectual content. }\end{array}$ \\
\hline
\end{tabular}

Appendix 1 (continued)

\begin{tabular}{llll}
\hline Name & Location & Role & Contribution \\
\hline $\begin{array}{l}\text { Anne } \\
\text { Rumpf, BS }\end{array}$ & PPD, Wilmington, NC & Author & $\begin{array}{l}\text { Reviewed and } \\
\text { curated data and } \\
\text { reviewed the } \\
\text { manuscript for } \\
\text { intellectual content. }\end{array}$ \\
& & & $\begin{array}{l}\text { Reviewed and } \\
\text { curated data and } \\
\text { reviewed the } \\
\text { Greer, BS }\end{array}$ \\
& PPD, Wilmington, NC & Author & \\
& & & $\begin{array}{l}\text { manuscript for } \\
\text { intellectual content. }\end{array}$ \\
& & &
\end{tabular}

\begin{tabular}{|c|c|c|c|}
\hline $\begin{array}{l}\text { Megan } \\
\text { Kenneally } \\
\text { Behne, AS }\end{array}$ & $\begin{array}{l}\text { The Guthy-Jackson } \\
\text { Charitable } \\
\text { Foundation, Beverly } \\
\text { Hills, CA }\end{array}$ & Author & $\begin{array}{l}\text { Reviewed and revised } \\
\text { the manuscript for } \\
\text { intellectual content. }\end{array}$ \\
\hline
\end{tabular}

\begin{tabular}{|c|c|c|c|}
\hline $\begin{array}{l}\text { Renee R. } \\
\text { Rodriguez, } \\
\text { AS }\end{array}$ & $\begin{array}{l}\text { The Guthy-Jackson } \\
\text { Charitable } \\
\text { Foundation, Beverly } \\
\text { Hills, CA }\end{array}$ & Author & $\begin{array}{l}\text { Reviewed and revised } \\
\text { the manuscript for } \\
\text { intellectual content. }\end{array}$ \\
\hline
\end{tabular}

\begin{tabular}{|c|c|c|c|}
\hline $\begin{array}{l}\text { Daniel W. } \\
\text { Behne, } \\
\text { MArch }\end{array}$ & $\begin{array}{l}\text { The Guthy-Jackson } \\
\text { Charitable } \\
\text { Foundation, Beverly } \\
\text { Hills, CA }\end{array}$ & Author & $\begin{array}{l}\text { Reviewed and revised } \\
\text { the manuscript for } \\
\text { intellectual content. }\end{array}$ \\
\hline
\end{tabular}

\begin{tabular}{|c|c|c|c|}
\hline $\begin{array}{l}\text { Derek W. } \\
\text { Blackway, } \\
\text { BA }\end{array}$ & $\begin{array}{l}\text { The Guthy-Jackson } \\
\text { Charitable } \\
\text { Foundation, Beverly } \\
\text { Hills, CA }\end{array}$ & Author & $\begin{array}{l}\text { Reviewed and revised } \\
\text { the manuscript for } \\
\text { intellectual content. }\end{array}$ \\
\hline
\end{tabular}

\begin{tabular}{|c|c|c|c|}
\hline $\begin{array}{l}\text { Brian } \\
\text { Coords, MA }\end{array}$ & $\begin{array}{l}\text { The Guthy-Jackson } \\
\text { Charitable } \\
\text { Foundation, Beverly }\end{array}$ & Author & $\begin{array}{l}\text { Reviewed and revisec } \\
\text { the manuscript for } \\
\text { intellectual content. }\end{array}$ \\
\hline
\end{tabular}

\begin{tabular}{llll}
\hline Terrence F. & Departments of & Author & Participated in study \\
Blaschke, & Medicine and of & & design; analyzed and
\end{tabular}

MD Molecular interpreted data;

Pharmacology, and reviewed and

Stanford University revised the

School of Medicine, manuscript for

Stanford, CA intellectual

content.

\begin{tabular}{|c|c|c|c|}
\hline $\begin{array}{l}\text { Judy } \\
\text { Sheard, } \\
\text { MPH, MA, } \\
\text { CCRC }\end{array}$ & $\begin{array}{l}\text { The Guthy-Jackson } \\
\text { Charitable } \\
\text { Foundation, Beverly } \\
\text { Hills, CA }\end{array}$ & Author & $\begin{array}{l}\text { Reviewed and } \\
\text { revised the } \\
\text { manuscript for } \\
\text { intellectual } \\
\text { content. }\end{array}$ \\
\hline
\end{tabular}

\begin{tabular}{|c|c|c|c|}
\hline $\begin{array}{l}\text { Terry J. } \\
\text { Smith, MD }\end{array}$ & $\begin{array}{l}\text { Kellogg Eye Center, } \\
\text { University of } \\
\text { Michigan Medical }\end{array}$ & Author & $\begin{array}{l}\text { Participated in study } \\
\text { design; analyzed and } \\
\text { interpreted data; }\end{array}$ \\
\hline
\end{tabular}
and drafted and revised the manuscript for intellectual content.

\begin{tabular}{|c|c|c|c|}
\hline $\begin{array}{l}\text { Jacinta M. } \\
\text { Behne, MA }\end{array}$ & $\begin{array}{l}\text { The Guthy-Jackson } \\
\text { Charitable } \\
\text { Foundation, Beverly } \\
\text { Hills, CA }\end{array}$ & Author & $\begin{array}{l}\text { Designed/ } \\
\text { conceptualized } \\
\text { study; interpreted } \\
\text { the data; and } \\
\text { revised the } \\
\text { manuscript for } \\
\text { intellectual content. }\end{array}$ \\
\hline
\end{tabular}

\begin{tabular}{|c|c|c|c|}
\hline $\begin{array}{l}\text { Michael R. } \\
\text { Yeaman, } \\
\text { PhD }\end{array}$ & $\begin{array}{l}\text { Department of } \\
\text { Medicine, University } \\
\text { of California, Los } \\
\text { Angeles, Los Angeles } \\
\text { CA; Harbor-UCLA } \\
\text { Medical Center/ } \\
\text { LABioMed, Torrance, } \\
\text { CA }\end{array}$ & Author & $\begin{array}{l}\text { Participated in study } \\
\text { design; analyzed and } \\
\text { interpreted data; } \\
\text { and drafted and } \\
\text { revised the } \\
\text { manuscript for } \\
\text { intellectual } \\
\text { content. }\end{array}$ \\
\hline
\end{tabular}


Appendix 2 Coinvestigators

\begin{tabular}{|c|c|c|c|}
\hline Name & Location & Role & Contribution \\
\hline $\begin{array}{l}\text { Hesham } \\
\text { Abboud, MD }\end{array}$ & $\begin{array}{l}\text { Multiple Sclerosis and } \\
\text { Neuroimmunology } \\
\text { Program, University } \\
\text { Hospitals of } \\
\text { Cleveland, Case } \\
\text { Western Reserve } \\
\text { University, Cleveland, } \\
\text { OH }\end{array}$ & Coinvestigator & $\begin{array}{l}\text { Reviewed and } \\
\text { revised the } \\
\text { manuscript } \\
\text { for } \\
\text { intellectual } \\
\text { content. }\end{array}$ \\
\hline $\begin{array}{l}\text { Orhan Aktas, } \\
\text { MD }\end{array}$ & $\begin{array}{l}\text { Heinrich Heine } \\
\text { Universität, } \\
\text { Düsseldorf, Germany }\end{array}$ & Coinvestigator & $\begin{array}{l}\text { Reviewed and } \\
\text { revised the } \\
\text { manuscript } \\
\text { for } \\
\text { intellectual } \\
\text { content. }\end{array}$ \\
\hline $\begin{array}{l}\text { Ayse Altintas, } \\
\text { MD }\end{array}$ & $\begin{array}{l}\text { Department of } \\
\text { Neurology, Koc } \\
\text { University, School of } \\
\text { Medicine, Istanbul, } \\
\text { Turkey }\end{array}$ & Coinvestigator & $\begin{array}{l}\text { Reviewed and } \\
\text { revised the } \\
\text { manuscript } \\
\text { for } \\
\text { intellectual } \\
\text { content. }\end{array}$ \\
\hline $\begin{array}{l}\text { Metha } \\
\text { Apiwattanakul, } \\
\text { MD }\end{array}$ & $\begin{array}{l}\text { Department of } \\
\text { Neurology, Prasat } \\
\text { Neurological Institute, } \\
\text { Bangkok, Thailand }\end{array}$ & Coinvestigator & $\begin{array}{l}\text { Reviewed and } \\
\text { revised the } \\
\text { manuscript } \\
\text { for } \\
\text { intellectual } \\
\text { content. }\end{array}$ \\
\hline $\begin{array}{l}\text { Nasrin Asgari, } \\
\text { MD, PhD }\end{array}$ & $\begin{array}{l}\text { Department of } \\
\text { Neurology, Slagelse } \\
\text { Hospital and } \\
\text { Institute of Regional } \\
\text { Health Research \& } \\
\text { Molecular Medicine, } \\
\text { University of } \\
\text { Southern Denmark, } \\
\text { Odense, Denmark }\end{array}$ & Coinvestigator & $\begin{array}{l}\text { Reviewed and } \\
\text { revised the } \\
\text { manuscript } \\
\text { for } \\
\text { intellectual } \\
\text { content. }\end{array}$ \\
\hline $\begin{array}{l}\text { Brenda } \\
\text { Banwell, MD }\end{array}$ & $\begin{array}{l}\text { Children's Hospital of } \\
\text { Philadelphia, } \\
\text { Perelman School of } \\
\text { Medicine, University } \\
\text { of Pennsylvania }\end{array}$ & Coinvestigator & $\begin{array}{l}\text { Reviewed and } \\
\text { revised the } \\
\text { manuscript } \\
\text { for } \\
\text { intellectual } \\
\text { content. }\end{array}$ \\
\hline $\begin{array}{l}\text { Denis Bichuetti, } \\
\text { MD }\end{array}$ & $\begin{array}{l}\text { Professor of } \\
\text { Neurology, Escola } \\
\text { Paulista de Medicina- } \\
\text { Universidade Federal } \\
\text { de São Paulo, Brazil }\end{array}$ & Coinvestigator & $\begin{array}{l}\text { Reviewed and } \\
\text { revised the } \\
\text { manuscript } \\
\text { for } \\
\text { intellectual } \\
\text { content. }\end{array}$ \\
\hline $\begin{array}{l}\text { James Bowen, } \\
\text { MD }\end{array}$ & $\begin{array}{l}\text { Multiple Sclerosis } \\
\text { Center, Swedish } \\
\text { Neuroscience } \\
\text { Institute, Seattle, WA }\end{array}$ & Coinvestigator & $\begin{array}{l}\text { Reviewed and } \\
\text { revised the } \\
\text { manuscript } \\
\text { for } \\
\text { intellectual } \\
\text { content. }\end{array}$ \\
\hline $\begin{array}{l}\text { Simon } \\
\text { Broadley, MD, } \\
\text { PhD }\end{array}$ & $\begin{array}{l}\text { Griffith University, } \\
\text { Queensland, Australia }\end{array}$ & Coinvestigator & $\begin{array}{l}\text { Reviewed and } \\
\text { revised the } \\
\text { manuscript } \\
\text { for } \\
\text { intellectual } \\
\text { content. }\end{array}$ \\
\hline $\begin{array}{l}\text { Wolfgang } \\
\text { Bruck, MD }\end{array}$ & $\begin{array}{l}\text { University Medical } \\
\text { Center Göttingen, } \\
\text { Germany }\end{array}$ & Coinvestigator & $\begin{array}{l}\text { Reviewed and } \\
\text { revised the } \\
\text { manuscript } \\
\text { for } \\
\text { intellectual } \\
\text { content. }\end{array}$ \\
\hline $\begin{array}{l}\text { Philippe Cabre, } \\
\text { MD }\end{array}$ & $\begin{array}{l}\text { CHU Pierre Zobda } \\
\text { Quitman, Martinique, } \\
\text { French West Indies }\end{array}$ & Coinvestigator & $\begin{array}{l}\text { Reviewed and } \\
\text { revised the } \\
\text { manuscript } \\
\text { for } \\
\text { intellectual } \\
\text { content. }\end{array}$ \\
\hline
\end{tabular}

Appendix 2 (continued)

\begin{tabular}{|c|c|c|c|}
\hline Name & Location & Role & Contribution \\
\hline $\begin{array}{l}\text { Jeffrey Cohen, } \\
\text { MD }\end{array}$ & $\begin{array}{l}\text { Mellen Center for MS } \\
\text { Treatment and } \\
\text { Research, } \\
\text { Neurological Institute, } \\
\text { Cleveland Clinic, } \\
\text { Cleveland, OH }\end{array}$ & Coinvestigator & $\begin{array}{l}\text { Reviewed and } \\
\text { revised the } \\
\text { manuscript } \\
\text { for } \\
\text { intellectual } \\
\text { content. }\end{array}$ \\
\hline $\begin{array}{l}\text { Jerome De Seze, } \\
\text { MD, PhD }\end{array}$ & $\begin{array}{l}\text { Chu de Strasbourg, } \\
\text { CIC Inserm 1434, } \\
\text { France }\end{array}$ & Coinvestigator & $\begin{array}{l}\text { Reviewed and } \\
\text { revised the } \\
\text { manuscript } \\
\text { for } \\
\text { intellectual } \\
\text { content. }\end{array}$ \\
\hline $\begin{array}{l}\text { Guillermo } \\
\text { Delgado-Garcia, } \\
\text { MD }\end{array}$ & $\begin{array}{l}\text { Division of Neurology, } \\
\text { National Institute of } \\
\text { Neurology and } \\
\text { Neurosurgery, Mexico } \\
\text { City, Mexico }\end{array}$ & Coinvestigator & $\begin{array}{l}\text { Reviewed and } \\
\text { revised the } \\
\text { manuscript for } \\
\text { intellectual } \\
\text { content. }\end{array}$ \\
\hline $\begin{array}{l}\text { Irena Dujmovic } \\
\text { Basuroski, MD, } \\
\text { PhD }\end{array}$ & $\begin{array}{l}\text { University of North } \\
\text { Carolina at Chapel Hill, } \\
\text { Department of } \\
\text { Neurology, Chapel } \\
\text { Hill, NC }\end{array}$ & Coinvestigator & $\begin{array}{l}\text { Reviewed and } \\
\text { revised the } \\
\text { manuscript for } \\
\text { intellectual } \\
\text { content. }\end{array}$ \\
\hline $\begin{array}{l}\text { Kazuo Fujihara, } \\
\text { MD }\end{array}$ & $\begin{array}{l}\text { Department of Multiple } \\
\text { Sclerosis Therapeutics, } \\
\text { Fukushima Medical } \\
\text { University, Fukushima, } \\
\text { Japan and Multiple } \\
\text { Sclerosis and } \\
\text { Neuromyelitis Optica } \\
\text { Center, Tohoku } \\
\text { Research Institute for } \\
\text { Neuroscience, } \\
\text { Koriyama, Japan }\end{array}$ & Coinvestigator & $\begin{array}{l}\text { Reviewed and } \\
\text { revised the } \\
\text { manuscript } \\
\text { for } \\
\text { intellectual } \\
\text { content. }\end{array}$ \\
\hline $\begin{array}{l}\text { Andrew } \\
\text { Goodman, MD }\end{array}$ & $\begin{array}{l}\text { Department of } \\
\text { Neurology, University } \\
\text { of Rochester Medical } \\
\text { Center, Rochester, NY }\end{array}$ & Coinvestigator & $\begin{array}{l}\text { Reviewed and } \\
\text { revised the } \\
\text { manuscript } \\
\text { for } \\
\text { intellectual } \\
\text { content. }\end{array}$ \\
\hline $\begin{array}{l}\text { Joachim Havla, } \\
\text { MD }\end{array}$ & $\begin{array}{l}\text { Institute of Clinical } \\
\text { Neuroimmunology, } \\
\text { Ludwig Maximilians } \\
\text { University, Munich, } \\
\text { Germany }\end{array}$ & Coinvestigator & $\begin{array}{l}\text { Reviewed and } \\
\text { revised the } \\
\text { manuscript } \\
\text { for } \\
\text { intellectual } \\
\text { content. }\end{array}$ \\
\hline $\begin{array}{l}\text { Kerstin Hellwig, } \\
\text { MD }\end{array}$ & $\begin{array}{l}\text { Department of } \\
\text { Neurology, St. Josef } \\
\text { Hospital Bochum, } \\
\text { Ruhr University, } \\
\text { Bochum, Germany }\end{array}$ & Coinvestigator & $\begin{array}{l}\text { Reviewed and } \\
\text { revised the } \\
\text { manuscript } \\
\text { for } \\
\text { intellectual } \\
\text { content. }\end{array}$ \\
\hline $\begin{array}{l}\text { Rogier Hintzen, } \\
\text { MD, PhD }\end{array}$ & $\begin{array}{l}\text { MS Centre ErasMS, } \\
\text { Dept of Neurology, } \\
\text { Erasmus MC, } \\
\text { Rotterdam, The } \\
\text { Netherlands }\end{array}$ & Coinvestigator & $\begin{array}{l}\text { Reviewed and } \\
\text { revised the } \\
\text { manuscript for } \\
\text { intellectual } \\
\text { content. }\end{array}$ \\
\hline $\begin{array}{l}\text { D. Craig Hooper, } \\
\text { PhD }\end{array}$ & $\begin{array}{l}\text { Department of Cancer } \\
\text { Biology, Thomas } \\
\text { Jefferson University, } \\
\text { Philadelphia, PA }\end{array}$ & Coinvestigator & $\begin{array}{l}\text { Reviewed and } \\
\text { revised the } \\
\text { manuscript } \\
\text { for } \\
\text { intellectual } \\
\text { content. }\end{array}$ \\
\hline $\begin{array}{l}\text { Raffaele lorio, } \\
\text { MD, PhD }\end{array}$ & $\begin{array}{l}\text { Institute of Neurology, } \\
\text { Fondazione Policlinico } \\
\text { Universitario "A. } \\
\text { Gemelli" IRCCS, } \\
\text { Università Cattolica } \\
\text { del Sacro Cuore, } \\
\text { Roma, Italy }\end{array}$ & Coinvestigator & $\begin{array}{l}\text { Reviewed and } \\
\text { revised the } \\
\text { manuscript } \\
\text { for } \\
\text { intellectual } \\
\text { content. }\end{array}$ \\
\hline
\end{tabular}

Continued 
Appendix 2 (continued)

\begin{tabular}{|c|c|c|c|c|c|c|c|}
\hline Name & Location & Role & Contribution & Name & Location & Role & Contribution \\
\hline Anu Jacob, MD & $\begin{array}{l}\text { The Walton Centre } \\
\text { NHS Trust and } \\
\text { University of } \\
\text { Liverpool, United } \\
\text { Kingdom }\end{array}$ & Coinvestigator & $\begin{array}{l}\text { Reviewed and } \\
\text { revised the } \\
\text { manuscript for } \\
\text { intellectual } \\
\text { content. }\end{array}$ & $\begin{array}{l}\text { M. Isabel Leite, } \\
\text { MD, D Phil }\end{array}$ & $\begin{array}{l}\text { Nuffield Department } \\
\text { of Clinical } \\
\text { Neurosciences. } \\
\text { University of Oxford } \\
\text { and Oxford University }\end{array}$ & Coinvestigator & $\begin{array}{l}\text { Reviewed and } \\
\text { revised the } \\
\text { manuscript } \\
\text { for intellectual } \\
\text { content. }\end{array}$ \\
\hline \multirow[t]{2}{*}{ Sven Jarius, MD } & \multirow{2}{*}{$\begin{array}{l}\text { Molecular } \\
\text { Neuroimmunology } \\
\text { Group, University of } \\
\text { Heidelberg, } \\
\text { Heidelberg, Germany }\end{array}$} & \multirow[t]{2}{*}{ Coinvestigator } & \multirow{2}{*}{$\begin{array}{l}\text { Reviewed and } \\
\text { revised the } \\
\text { manuscript for } \\
\text { intellectual } \\
\text { content. }\end{array}$} & & $\begin{array}{l}\text { Way, Oxford OX3 9DU, } \\
\text { UK }\end{array}$ & & \\
\hline & & & & $\begin{array}{l}\text { Yaou Liu, MD, } \\
\text { PhD }\end{array}$ & $\begin{array}{l}\text { Department of } \\
\text { Radiology, Beijing }\end{array}$ & Coinvestigator & $\begin{array}{l}\text { Reviewed and } \\
\text { revised the }\end{array}$ \\
\hline \multirow[t]{2}{*}{$\begin{array}{l}\text { Jorge Andres } \\
\text { Jimenez } \\
\text { Arango, MD }\end{array}$} & \multirow[t]{2}{*}{$\begin{array}{l}\text { Universidad de } \\
\text { Antioquia, } \\
\text { Neuroclinica, } \\
\text { Colombia }\end{array}$} & \multirow[t]{2}{*}{ Coinvestigator } & \multirow[t]{2}{*}{$\begin{array}{l}\text { Reviewed and } \\
\text { revised the } \\
\text { manuscript for } \\
\text { intellectual } \\
\text { content. }\end{array}$} & & $\begin{array}{l}\text { Capital Medical } \\
\text { University, } \\
\text { Beijing 100050; } \\
\text { China }\end{array}$ & & $\begin{array}{l}\text { intellectual } \\
\text { content. }\end{array}$ \\
\hline & & & & Fred Lublin, MD & Mount Sinai Medical & Coinvestigator & Reviewed and \\
\hline $\begin{array}{l}\text { Gareth John, } \\
\text { PhD }\end{array}$ & $\begin{array}{l}\text { The Mount Sinai } \\
\text { Hospital, New York, NY }\end{array}$ & Coinvestigator & $\begin{array}{l}\text { Reviewed and } \\
\text { revised the } \\
\text { manuscript for } \\
\text { intellectual } \\
\text { content. }\end{array}$ & & Center, New York, NY & & $\begin{array}{l}\text { revised the } \\
\text { manuscript for } \\
\text { intellectual } \\
\text { content. }\end{array}$ \\
\hline \multirow[t]{2}{*}{$\begin{array}{l}\text { Ho Jin Kim, MD, } \\
\text { PhD }\end{array}$} & \multirow{2}{*}{$\begin{array}{l}\text { Department of } \\
\text { Neurology, Research } \\
\text { Institute and Hospital } \\
\text { of National Cancer } \\
\text { Center, Goyang, } \\
\text { Republic of Korea }\end{array}$} & \multirow[t]{2}{*}{ Coinvestigator } & \multirow{2}{*}{$\begin{array}{l}\text { Reviewed and } \\
\text { revised the } \\
\text { manuscript } \\
\text { for } \\
\text { intellectual } \\
\text { content. }\end{array}$} & $\begin{array}{l}\text { Youssoufa } \\
\text { Maiga, MD }\end{array}$ & $\begin{array}{l}\text { Faculty of Medicine, } \\
\text { University of Technical } \\
\text { Sciences and } \\
\text { Technologies, } \\
\text { Bamako, Mali }\end{array}$ & Coinvestigator & $\begin{array}{l}\text { Reviewed and } \\
\text { revised the } \\
\text { manuscript for } \\
\text { intellectual } \\
\text { content. }\end{array}$ \\
\hline & & & & $\begin{array}{l}\text { Yang Mao- } \\
\text { Draayer, MD, }\end{array}$ & $\begin{array}{l}\text { Graduate Program in } \\
\text { Immunology, }\end{array}$ & Coinvestigator & $\begin{array}{l}\text { Reviewed and } \\
\text { revised the }\end{array}$ \\
\hline $\begin{array}{l}\text { Sung Min Kim, } \\
\text { MD, PhD }\end{array}$ & $\begin{array}{l}\text { Department of } \\
\text { Neurology, Seoul } \\
\text { National University } \\
\text { Hospital, Seoul, Korea }\end{array}$ & Coinvestigator & $\begin{array}{l}\text { Reviewed and } \\
\text { revised the } \\
\text { manuscript } \\
\text { for } \\
\text { intellectual } \\
\text { content. }\end{array}$ & PhD & $\begin{array}{l}\text { Program in } \\
\text { Biomedical Sciences, } \\
\text { Department of } \\
\text { Neurology, University } \\
\text { of Michigan Medical } \\
\text { School }\end{array}$ & & $\begin{array}{l}\text { manuscript } \\
\text { for } \\
\text { intellectual } \\
\text { content. }\end{array}$ \\
\hline $\begin{array}{l}\text { Dorlan J. } \\
\text { Kimbrough, MD }\end{array}$ & $\begin{array}{l}\text { Harvard Medical } \\
\text { School, Brigham \& } \\
\text { Women's Hospital } \\
\text { Department of } \\
\text { Neurology, Boston, } \\
\text { MA }\end{array}$ & Coinvestigator & $\begin{array}{l}\text { Reviewed and } \\
\text { revised the } \\
\text { manuscript } \\
\text { for } \\
\text { intellectual } \\
\text { content. }\end{array}$ & $\begin{array}{l}\text { Romain } \\
\text { Marignier, MD, } \\
\text { PhD }\end{array}$ & $\begin{array}{l}\text { Service de neurologie, } \\
\text { sclérose en plaques, } \\
\text { pathologies de la } \\
\text { myéline et neuro- } \\
\text { inflammation and } \\
\text { Centre de référence } \\
\text { pour les maladies }\end{array}$ & Coinvestigator & $\begin{array}{l}\text { Reviewed and } \\
\text { revised the } \\
\text { manuscript } \\
\text { for } \\
\text { intellectual } \\
\text { content. }\end{array}$ \\
\hline \multirow[t]{2}{*}{$\begin{array}{l}\text { Najib Kissani, } \\
\text { MD }\end{array}$} & \multirow[t]{2}{*}{$\begin{array}{l}\text { Department of } \\
\text { Neurology, Mohamed } \\
\text { VI University Hospital; } \\
\text { Neuroscience } \\
\text { Research Laboratory, } \\
\text { Marrakech Medical } \\
\text { School; UCA, } \\
\text { Marrakech, } \\
\text { Morocco }\end{array}$} & \multirow[t]{2}{*}{ Coinvestigator } & \multirow[t]{2}{*}{$\begin{array}{l}\text { Reviewed and } \\
\text { revised the } \\
\text { manuscript } \\
\text { for } \\
\text { intellectual } \\
\text { content. }\end{array}$} & & $\begin{array}{l}\text { inflammatoires rares } \\
\text { du cerveau et de la } \\
\text { moelle (MIRCEM) - } \\
\text { Hôpital Neurologique } \\
\text { Pierre Wertheimer } \\
\text { Hospices Civils de } \\
\text { Lyon, Lyon, F-6977, } \\
\text { France }\end{array}$ & & \\
\hline & & & & Marcelo & Assistant Professor of & Coinvestigator & Reviewed and \\
\hline \multirow[t]{2}{*}{ Ingo Kleiter, MD } & \multirow{2}{*}{$\begin{array}{l}\text { Marianne-Strauß- } \\
\text { Klinik, } \\
\text { Behandlungszentrum } \\
\text { Kempfenhausen für } \\
\text { Multiple Sklerose } \\
\text { Kranke, Berg, Germany; } \\
\text { Department of } \\
\text { Neurology, St. Josef } \\
\text { Hospital, Ruhr } \\
\text { University Bochum, } \\
\text { Bochum, Germany }\end{array}$} & \multirow[t]{2}{*}{ Coinvestigator } & \multirow{2}{*}{$\begin{array}{l}\text { Reviewed and } \\
\text { revised the } \\
\text { manuscript } \\
\text { for } \\
\text { intellectual } \\
\text { content. }\end{array}$} & Matiello, MD & $\begin{array}{l}\text { Neurology, Harvard } \\
\text { Medical School }\end{array}$ & & $\begin{array}{l}\text { revised the } \\
\text { manuscript for } \\
\text { intellectual } \\
\text { content. }\end{array}$ \\
\hline & & & & $\begin{array}{l}\text { Callene } \\
\text { Momtazee, MD }\end{array}$ & $\begin{array}{l}\text { Department of } \\
\text { Neurology, University } \\
\text { of California, Los } \\
\text { Angeles, Los Angeles, } \\
\text { CA }\end{array}$ & Coinvestigator & $\begin{array}{l}\text { Reviewed and } \\
\text { revised the } \\
\text { manuscript for } \\
\text { intellectual } \\
\text { content. }\end{array}$ \\
\hline $\begin{array}{l}\text { Marco Lana- } \\
\text { Peixoto, MD, } \\
\text { PhD }\end{array}$ & $\begin{array}{l}\text { Federal University of } \\
\text { Minas Gerais Medical } \\
\text { School, Belo } \\
\text { Horizonte, Brazil }\end{array}$ & Coinvestigator & $\begin{array}{l}\text { Reviewed and } \\
\text { revised the } \\
\text { manuscript } \\
\text { for } \\
\text { intellectual } \\
\text { content. }\end{array}$ & $\begin{array}{l}\text { Mark Morrow, } \\
\text { MD }\end{array}$ & $\begin{array}{l}\text { Department of } \\
\text { Neurology, Harbor- } \\
\text { UCLA Medical Center, } \\
\text { Torrance, CA; David } \\
\text { Geffen School of } \\
\text { Medicine, Los Angeles, } \\
\text { CA }\end{array}$ & Coinvestigator & $\begin{array}{l}\text { Reviewed and } \\
\text { revised the } \\
\text { manuscript } \\
\text { for } \\
\text { intellectual } \\
\text { content. }\end{array}$ \\
\hline $\begin{array}{l}\text { Annette } \\
\text { Langer-Gould, } \\
\text { MD, PhD }\end{array}$ & $\begin{array}{l}\text { Kaiser Permanente } \\
\text { Southern California, } \\
\text { CA }\end{array}$ & Coinvestigator & $\begin{array}{l}\text { Reviewed and } \\
\text { revised the } \\
\text { manuscript } \\
\text { for } \\
\text { intellectual } \\
\text { content. }\end{array}$ & $\begin{array}{l}\text { Ichiro } \\
\text { Nakashima, MD }\end{array}$ & $\begin{array}{l}\text { Department of } \\
\text { Neurology, Tohoku } \\
\text { Medical and } \\
\text { Pharmaceutical } \\
\text { University, Sendai, } \\
\text { Japan }\end{array}$ & Coinvestigator & $\begin{array}{l}\text { Reviewed and } \\
\text { revised the } \\
\text { manuscript } \\
\text { for } \\
\text { intellectual } \\
\text { content. }\end{array}$ \\
\hline
\end{tabular}

Appendix 2 (continued)

Marcelo Assistant Professor of Coinvestigator Reviewed and revised the manuscript for intellectual Reviewed and 
Appendix 2 (continued)

\begin{tabular}{|c|c|c|c|c|c|c|c|}
\hline Name & Location & Role & Contribution & Name & Location & Role & Contribution \\
\hline $\begin{array}{l}\text { Kevin O'Connor, } \\
\text { PhD }\end{array}$ & $\begin{array}{l}\text { Yale University School } \\
\text { of Medicine, New } \\
\text { Haven, CT }\end{array}$ & Coinvestigator & $\begin{array}{l}\text { Reviewed and } \\
\text { revised the } \\
\text { manuscript } \\
\text { for } \\
\text { intellectual } \\
\text { content. }\end{array}$ & Chao Quan, MD & $\begin{array}{l}\text { Department of } \\
\text { Neurology, Huashan } \\
\text { Hospital, Shanghai } \\
\text { Medical College, } \\
\text { Fudan University }\end{array}$ & Coinvestigator & $\begin{array}{l}\text { Reviewed and } \\
\text { revised the } \\
\text { manuscript } \\
\text { for } \\
\text { intellectual } \\
\text { content. }\end{array}$ \\
\hline $\begin{array}{l}\text { Celia Oreja- } \\
\text { Guevara, MD, } \\
\text { PhD }\end{array}$ & $\begin{array}{l}\text { Hospital Clinico San } \\
\text { Carlos, Neurology and } \\
\text { Universidad } \\
\text { Complutense Madrid, } \\
\text { Spain }\end{array}$ & Coinvestigator & $\begin{array}{l}\text { Reviewed and } \\
\text { revised the } \\
\text { manuscript } \\
\text { for } \\
\text { intellectual } \\
\text { content. }\end{array}$ & $\begin{array}{l}\text { Marius } \\
\text { Ringelstein, MD }\end{array}$ & $\begin{array}{l}\text { Department of } \\
\text { Neurology, Medical } \\
\text { Faculty, Heinrich } \\
\text { Heine University } \\
\text { Düsseldorf, } \\
\text { Düsseldorf, Germany }\end{array}$ & Coinvestigator & $\begin{array}{l}\text { Reviewed and } \\
\text { revised the } \\
\text { manuscript } \\
\text { for } \\
\text { intellectual } \\
\text { content. }\end{array}$ \\
\hline $\begin{array}{l}\text { Jacqueline } \\
\text { Palace, MD }\end{array}$ & $\begin{array}{l}\text { Department of } \\
\text { Neurology, Oxford } \\
\text { University Hospital } \\
\text { Trust, Oxford, United } \\
\text { Kingdom }\end{array}$ & Coinvestigator & $\begin{array}{l}\text { Reviewed and } \\
\text { revised the } \\
\text { manuscript for } \\
\text { intellectual } \\
\text { content. }\end{array}$ & $\begin{array}{l}\text { Victor Rivera, } \\
\text { MD }\end{array}$ & $\begin{array}{l}\text { Baylor College of } \\
\text { Medicine, Houston, TX }\end{array}$ & Coinvestigator & $\begin{array}{l}\text { Reviewed and } \\
\text { revised the } \\
\text { manuscript for } \\
\text { intellectual } \\
\text { content. }\end{array}$ \\
\hline $\begin{array}{l}\text { Lekha Pandit, } \\
\text { MD, PhD }\end{array}$ & $\begin{array}{l}\text { Nitte University, } \\
\text { Mangalore, India }\end{array}$ & Coinvestigator & $\begin{array}{l}\text { Reviewed and } \\
\text { revised the } \\
\text { manuscript for } \\
\text { intellectual } \\
\text { content. }\end{array}$ & $\begin{array}{l}\text { Dalia L. } \\
\text { Rotstein, MD }\end{array}$ & $\begin{array}{l}\text { University of Toronto, } \\
\text { Department of } \\
\text { Medicine, Division of } \\
\text { Neurology }\end{array}$ & Coinvestigator & $\begin{array}{l}\text { Reviewed and } \\
\text { revised the } \\
\text { manuscript } \\
\text { for } \\
\text { intellectual } \\
\text { content. }\end{array}$ \\
\hline \multirow[t]{3}{*}{$\begin{array}{l}\text { Friedemann } \\
\text { Paul, MD }\end{array}$} & \multirow{3}{*}{$\begin{array}{l}\text { Charité - } \\
\text { Universitätsmedizin } \\
\text { Berlin, corporate } \\
\text { member of Freie } \\
\text { Universität Berlin, } \\
\text { Humboldt-Universität } \\
\text { zu Berlin, and Berlin } \\
\text { Institute of Health, } \\
\text { Neurocure Cluster of } \\
\text { Excellence, NeuroCure } \\
\text { Clinical Research } \\
\text { Center, Berlin, } \\
\text { Germany; Experimental } \\
\text { and Clinical Research } \\
\text { Center, Charité - } \\
\text { Universitätsmedizin } \\
\text { Berlin corporate } \\
\text { member of Freie } \\
\text { Universität Berlin, } \\
\text { Humboldt-Universität } \\
\text { zu Berlin, and Berlin } \\
\text { Institute of Health and } \\
\text { Max Delbrück Center } \\
\text { for Molecular Medicine, } \\
\text { Berlin-Buch, Germany }\end{array}$} & \multirow[t]{3}{*}{ Coinvestigator } & \multirow[t]{3}{*}{$\begin{array}{l}\text { Reviewed and } \\
\text { revised the } \\
\text { manuscript } \\
\text { for } \\
\text { intellectual } \\
\text { content. }\end{array}$} & $\begin{array}{l}\text { Klemens } \\
\text { Ruprecht, MD }\end{array}$ & $\begin{array}{l}\text { Department of } \\
\text { Neurology, Charité - } \\
\text { Universitätsmedizin } \\
\text { Berlin, corporate } \\
\text { member of Freie } \\
\text { Universität Berlin, } \\
\text { Humboldt-Universität } \\
\text { zu Berlin, and Berlin } \\
\text { Institute of Health, } \\
\text { Berlin, Germany }\end{array}$ & Coinvestigator & $\begin{array}{l}\text { Reviewed and } \\
\text { revised the } \\
\text { manuscript } \\
\text { for } \\
\text { intellectual } \\
\text { content. }\end{array}$ \\
\hline & & & & $\begin{array}{l}\text { Maria José Sá, } \\
\text { MD, PhD }\end{array}$ & $\begin{array}{l}\text { Neurology } \\
\text { Department, Centro } \\
\text { Hospitalar de São } \\
\text { João, FP-ENAS (UFP } \\
\text { Energy, Environment } \\
\text { and Health Research } \\
\text { Unit), Faculty of Health } \\
\text { Sciences, University } \\
\text { Fernando Pessoa, } \\
\text { Porto, Portugal }\end{array}$ & Coinvestigator & $\begin{array}{l}\text { Reviewed and } \\
\text { revised the } \\
\text { manuscript } \\
\text { for } \\
\text { intellectual } \\
\text { content. }\end{array}$ \\
\hline & & & & $\begin{array}{l}\text { Albert Saiz, MD, } \\
\text { PhD }\end{array}$ & $\begin{array}{l}\text { Hospital Clinic and } \\
\text { Institut d' Investigaciò }\end{array}$ & Coinvestigator & $\begin{array}{l}\text { Reviewed and } \\
\text { revised the }\end{array}$ \\
\hline \multirow[t]{2}{*}{$\begin{array}{l}\text { Naraporn } \\
\text { Prayoonwiwat, } \\
\text { MD }\end{array}$} & \multirow{2}{*}{$\begin{array}{l}\text { Division of Neurology, } \\
\text { Department of } \\
\text { Medicine, Faculty of } \\
\text { Medicine Siriraj } \\
\text { Hospital, Mahidol } \\
\text { University, Bangkok, } \\
\text { Thailand }\end{array}$} & \multirow[t]{2}{*}{ Coinvestigator } & \multirow{2}{*}{$\begin{array}{l}\text { Reviewed and } \\
\text { revised the } \\
\text { manuscript for } \\
\text { intellectual } \\
\text { content. }\end{array}$} & & $\begin{array}{l}\text { (IDIBAPS), University } \\
\text { of Barcelona, } \\
\text { Barcelona, Spain }\end{array}$ & & $\begin{array}{l}\text { for } \\
\text { intellectual } \\
\text { content. }\end{array}$ \\
\hline & & & & $\begin{array}{l}\text { Ché Serguera, } \\
\text { MD, PhD }\end{array}$ & $\begin{array}{l}\text { CEA, Molecular } \\
\text { Imaging Research } \\
\text { Center (MIRCen), }\end{array}$ & Coinvestigator & $\begin{array}{l}\text { Reviewed and } \\
\text { revised the } \\
\text { manuscript }\end{array}$ \\
\hline \multirow[t]{3}{*}{$\begin{array}{l}\text { Anne-Katrin } \\
\text { Pröbstel, MD }\end{array}$} & \multirow{3}{*}{$\begin{array}{l}\text { Neurologic Clinic and } \\
\text { Policlinic, Departments } \\
\text { of Medicine, and } \\
\text { Biomedicine, University } \\
\text { Hospital, University of } \\
\text { Basel, Basel, } \\
\text { Switzerland; UCSF Weill } \\
\text { Institute for } \\
\text { Neurosciences, } \\
\text { Department of } \\
\text { Neurology, University of } \\
\text { California San Francisco, } \\
\text { San Francisco, CA }\end{array}$} & \multirow[t]{3}{*}{ Coinvestigator } & \multirow{3}{*}{$\begin{array}{l}\text { Reviewed and } \\
\text { revised the } \\
\text { manuscript } \\
\text { for } \\
\text { intellectual } \\
\text { content. }\end{array}$} & & aux-Roses, France & & $\begin{array}{l}\text { intellectual } \\
\text { content. }\end{array}$ \\
\hline & & & & $\begin{array}{l}\text { Eslam Shosha, } \\
\text { MD }\end{array}$ & $\begin{array}{l}\text { College of Medicine, Al } \\
\text { Majmaah University, } \\
\text { Riyadh, Saudi Arabia }\end{array}$ & Coinvestigator & $\begin{array}{l}\text { Reviewed and } \\
\text { revised the } \\
\text { manuscript for } \\
\text { intellectual } \\
\text { content. }\end{array}$ \\
\hline & & & & \multirow[t]{2}{*}{$\begin{array}{l}\text { Sasitorn Siritho, } \\
\text { MD }\end{array}$} & \multirow{2}{*}{$\begin{array}{l}\text { Multiple Sclerosis and } \\
\text { Related Disorder } \\
\text { Clinics, Siriraj } \\
\text { Hospital, Mahidol } \\
\text { University, Bangkok, } \\
\text { Thailand; } \\
\text { Bumrungrad } \\
\text { International } \\
\text { Hospital, Bangkok, } \\
\text { Thailand }\end{array}$} & \multirow[t]{2}{*}{ Coinvestigator } & \multirow{2}{*}{$\begin{array}{l}\text { Reviewed and } \\
\text { revised the } \\
\text { manuscript } \\
\text { for } \\
\text { intellectual } \\
\text { content. }\end{array}$} \\
\hline $\begin{array}{l}\text { Peiqing Qian, } \\
\text { MD }\end{array}$ & $\begin{array}{l}\text { MS Center at Swedish } \\
\text { Medical Center, } \\
\text { Seattle, WA }\end{array}$ & Coinvestigator & $\begin{array}{l}\text { Reviewed and } \\
\text { revised the } \\
\text { manuscript } \\
\text { for } \\
\text { intellectual } \\
\text { content. }\end{array}$ & & & & \\
\hline
\end{tabular}

Appendix 2 (continued)

Continued 
Appendix 2 (continued)

\begin{tabular}{|c|c|c|c|}
\hline Name & Location & Role & Contribution \\
\hline Aksel Siva, MD & $\begin{array}{l}\text { Department of } \\
\text { Neurology, Clinical } \\
\text { Neuroimmunology } \\
\text { Unit, Istanbul } \\
\text { University } \\
\text { Cerrahpasa } \\
\text { School of } \\
\text { Medicine, Istanbul, } \\
\text { Turkey }\end{array}$ & Coinvestigator & $\begin{array}{l}\text { Reviewed and } \\
\text { revised the } \\
\text { manuscript for } \\
\text { intellectual } \\
\text { content. }\end{array}$ \\
\hline $\begin{array}{l}\text { Ibis Soto de } \\
\text { Castillo, MD }\end{array}$ & $\begin{array}{l}\text { Neurology } \\
\text { Department, Hospital } \\
\text { Universitario de } \\
\text { Maracaibo, } \\
\text { Maracaibo, Venezuela }\end{array}$ & Coinvestigator & $\begin{array}{l}\text { Reviewed and } \\
\text { revised the } \\
\text { manuscript for } \\
\text { intellectual } \\
\text { content. }\end{array}$ \\
\hline $\begin{array}{l}\text { Olaf Stuve, MD, } \\
\text { PhD }\end{array}$ & $\begin{array}{l}\text { UT Southwestern } \\
\text { Medical Center, } \\
\text { Dallas, TX }\end{array}$ & Coinvestigator & $\begin{array}{l}\text { Reviewed and } \\
\text { revised the } \\
\text { manuscript for } \\
\text { intellectual } \\
\text { content. }\end{array}$ \\
\hline $\begin{array}{l}\text { Silvia } \\
\text { Tenembaum, } \\
\text { MD }\end{array}$ & $\begin{array}{l}\text { Department of } \\
\text { Neurology, National } \\
\text { Pediatric Hospital Dr. } \\
\text { J. P. Garrahan. Buenos } \\
\text { Aires, Argentina }\end{array}$ & Coinvestigator & $\begin{array}{l}\text { Reviewed and } \\
\text { revised the } \\
\text { manuscript } \\
\text { for } \\
\text { intellectual } \\
\text { content. }\end{array}$ \\
\hline $\begin{array}{l}\text { Pablo } \\
\text { Villoslada, MD }\end{array}$ & $\begin{array}{l}\text { Institute } \\
\text { d'Investigacions } \\
\text { Biomediques August } \\
\text { Pi Sunyer (IDIBAPS), } \\
\text { Barcelona, Spain }\end{array}$ & Coinvestigator & $\begin{array}{l}\text { Reviewed and } \\
\text { revised the } \\
\text { manuscript } \\
\text { for } \\
\text { intellectual } \\
\text { content. }\end{array}$ \\
\hline $\begin{array}{l}\text { Dean } \\
\text { Wingerchuk, } \\
\text { MD }\end{array}$ & $\begin{array}{l}\text { Mayo Clinic, } \\
\text { Scottsdale, AZ }\end{array}$ & Coinvestigator & $\begin{array}{l}\text { Reviewed and } \\
\text { revised the } \\
\text { manuscript } \\
\text { for } \\
\text { intellectual } \\
\text { content. }\end{array}$ \\
\hline Jens Würfel, MD & $\begin{array}{l}\text { MIAC AG, Basel, } \\
\text { Switzerland }\end{array}$ & Coinvestigator & $\begin{array}{l}\text { Reviewed and } \\
\text { revised the } \\
\text { manuscript } \\
\text { for } \\
\text { intellectual } \\
\text { content. }\end{array}$ \\
\hline E. Ann Yeh, MD & $\begin{array}{l}\text { Division of Neurology, } \\
\text { Hospital for Sick } \\
\text { Children, University of } \\
\text { Toronto, Canada }\end{array}$ & Coinvestigator & $\begin{array}{l}\text { Reviewed and } \\
\text { revised the } \\
\text { manuscript } \\
\text { for } \\
\text { intellectual } \\
\text { content. }\end{array}$ \\
\hline $\begin{array}{l}\text { Scott S. Zamvil, } \\
\text { MD, PhD }\end{array}$ & $\begin{array}{l}\text { Department of } \\
\text { Neurology and } \\
\text { Program in } \\
\text { Immunology, } \\
\text { University of } \\
\text { California, San } \\
\text { Francisco, San } \\
\text { Francisco, CA }\end{array}$ & Coinvestigator & $\begin{array}{l}\text { Reviewed and } \\
\text { revised the } \\
\text { manuscript } \\
\text { for } \\
\text { intellectual } \\
\text { content. }\end{array}$ \\
\hline
\end{tabular}

\section{References}

1. Akaishi T, Nakashima I, Sato DK, Takahashi T, Fujihara K. Neuromyelitis optica spectrum disorders. Neuroimaging Clin N Am 2017;27:251-265.

2. Marignier R, Cobo Calvo A, Vukusic S. Neuromyelitis optica and neuromyelitis optica spectrum disorders. Curr Opin Neurol 2017;30:208-215.

3. Weinshenker BG, Wingerchuk DM. Neuromyelitis spectrum disorders. Mayo Clin Proc 2017;92:663-679.

4. Whittam D, Wilson M, Hamid S, Keir G, Bhojak M, Jacob A. What's new in neuromyelitis optica? A short review for the clinical neurologist. J Neurol 2017;264:2330-2344.

5. Flanagan EP, Cabre P, Weinshenker BG, et al. Epidemiology of aquaporin-4 autoimmunity and neuromyelitis optica spectrum. Ann Neurol 2016;79:775-783.

6. Houzen H, Kondo K, Niino M, et al. Prevalence and clinical features of neuromyelitis optica spectrum disorders in northern Japan. Neurology 2017;89:1995-2001.
7. Sepulveda M, Aldea M, Escudero D, et al. Epidemiology of NMOSD in Catalonia: influence of the new 2015 criteria in incidence and prevalence estimates. Mult Scler 2017 Epub 2017 Oct 1.

8. Pandit L, Asgari N, Apiwattanakul M, et al. Demographic and clinical features of neuromyelitis optica: a review. Mult Scler 2015;21:845-853.

9. Borisow N, Kleiter I, Gahlen A, et al. Influence of female sex and fertile age on neuromyelitis optica spectrum disorders. Mult Scler 2017;23:1092-1103.

10. Sepulveda M, Armangue T, Sola-Valls N, et al. Neuromyelitis optica spectrum disorders: comparison according to the phenotype and serostatus. Neurol Neuroimmunol Neuroinflamm 2016;3:e225. doi:10.1212/NXI.0000000000000225.

11. Kim HJ, Paul F, Lana-Peixoto MA, et al. MRI characteristics of neuromyelitis optica spectrum disorder: an international update. Neurology 2015;84:1165-1173.

12. Paul F, Murphy O, Pardo S, Levy M. Investigational drugs in development to prevent neuromyelitis optica relapses. Expert Opin Investig Drugs 2018;27:265-271.

13. Trebst C, Jarius S, Berthele A, et al. Update on the diagnosis and treatment of neuromyelitis optica: recommendations of the Neuromyelitis Optica Study Group (NEMOS). J Neurol 2014;261:1-16.

14. Wingerchuk DM, Banwell B, Bennett JL, et al. International consensus diagnostic criteria for neuromyelitis optica spectrum disorders. Neurology 2015;85:177-189.

15. Jarius S, Kleiter I, Ruprecht K, et al. MOG-IgG in NMO and related disorders: a multicenter study of 50 patients. Part 3: brainstem involvement-frequency, presentation and outcome. J Neuroinflammation 2016;13:281.

16. Jarius S, Ruprecht $\mathrm{K}$, Kleiter I, et al. MOG-IgG in NMO and related disorders: a multicenter study of 50 patients. Part 2: epidemiology, clinical presentation, radiological and laboratory features, treatment responses, and long-term outcome. J Neuroinflammation 2016;13:280.

17. Jarius S, Ruprecht K, Kleiter I, et al. MOG-IgG in NMO and related disorders: a multicenter study of 50 patients. Part 1: frequency, syndrome specificity, influence of disease activity, long-term course, association with AQP4-IgG, and origin. J Neuroinflammation 2016;13:279.

18. Kleiter I, Gahlen A, Borisow N, et al. Neuromyelitis optica: evaluation of 871 attacks and 1,153 treatment courses. Ann Neurol 2016;79:206-216.

19. Mealy MA, Wingerchuk DM, Greenberg BM, Levy M. Epidemiology of neuromyelitis optica in the United States: a multicenter analysis. Arch Neurol 2012;69:1176-1180.

20. Pache F, Zimmermann H, Mikolajczak J, et al. MOG-IgG in NMO and related disorders: a multicenter study of 50 patients. Part 4: afferent visual system damage after optic neuritis in MOG-IgG-seropositive versus AQP4-IgG-seropositive patients. J Neuroinflammation 2016;13:282.

21. Collongues N, Marignier R, Zephir H, et al. Neuromyelitis optica in France: a multicenter study of 125 patients. Neurology 2010;74:736-742.

22. Jarius S, Ruprecht $\mathrm{K}$, Wildemann B, et al. Contrasting disease patterns in seropositive and seronegative neuromyelitis optica: a multicentre study of 175 patients. J Neuroinflammation 2012;9:14

23. Ngo ST, Steyn FJ, McCombe PA. Gender differences in autoimmune disease. Front Neuroendocrinol 2014;35:347-369.

24. Tackley G, O’Brien F, Rocha J, et al. Neuromyelitis optica relapses: race and rate, immunosuppression and impairment. Mult Scler Relat Disord 2016;7:21-25.

25. ZhangBao J, Zhou L, Li X, et al. The clinical characteristics of AQP4 antibody positive NMO/SD in a large cohort of Chinese Han patients. J Neuroimmunol 2017;302:49-55.

26. Wingerchuk DM, Lennon VA, Pittock SJ, Lucchinetti CF, Weinshenker BG. Revised diagnostic criteria for neuromyelitis optica. Neurology 2006;66:1485-1489.

27. Asgari N, Lillevang ST, Skejoe HP, Falah M, Stenager E, Kyvik KO. A population based study of neuromyelitis optica in Caucasians. Neurology 2011;76:1589-1595.

28. Jacob A, Panicker J, Lythgoe D, et al. The epidemiology of neuromyelitis optica amongst adults in the Merseyside county of United Kingdom. J Neurol 2013;260:2134-2137.

29. Cossburn M, Tackley G, Baker K, et al. The prevalence of neuromyelitis optica in South East Wales. Eur J Neurol 2012;19:655-659.

30. Cabre P, Gonzalez-Quevedo A, Lannuzel A, et al. Descriptive epidemiology of neuromyelitis optica in the Caribbean basin [in French]. Rev Neurol (Paris) 2009;165:676-683.

31. Pandit L, Kundapur R. Prevalence and patterns of demyelinating central nervous system disorders in urban Mangalore, South India. Mult Scler 2014;20:1651-1653.

32. Mori M, Kuwabara S, Paul F. Worldwide prevalence of neuromyelitis optica spectrum disorders. J Neurol Neurosurg Psychiatry 2018;89:555-556.

33. Spadaro M, Gerdes LA, Krumbholz M, et al. Autoantibodies to MOG in a distinct subgroup of adult multiple sclerosis. Neurol Neuroimmunol Neuroinflamm 2016;3: e257. doi:10.1212/NXI.0000000000000257.

34. Zamvil SS, Slavin AJ. Does MOG Ig-positive AQP4-seronegative opticospinal in flammatory disease justify a diagnosis of NMO spectrum disorder? Neurol Neuroimmunol Neuroinflamm 2015;2:e62. doi:10.1212/NXI.0000000000000062.

35. Reindl M, Rostasy K. MOG antibody-associated diseases. Neurol Neuroimmunol Neuroinflamm 2015;2:e60. doi:10.1212/NXI.0000000000000060.

36. Kremer S, Renard F, Achard S, et al. Use of advanced magnetic resonance imaging techniques in neuromyelitis optica spectrum disorder. JAMA Neurol 2015;72:815-822.

37. Melamed E, Levy M, Waters PJ, et al. Update on biomarkers in neuromyelitis optica. Neurol Neuroimmunol Neuroinflamm 2015;2:e134. doi:10.1212/NXI.0000000000000134.

38. Chavarro VS, Mealy MA, Simpson A, et al. Insufficient treatment of severe depression in neuromyelitis optica spectrum disorder. Neurol Neuroimmunol Neuroinflamm 2016;3:e286. doi:10.1212/NXI.0000000000000286.

39. Penner IK, Paul F. Fatigue as a symptom or comorbidity of neurological diseases. Nat Rev Neurol 2017;13:662-675.

40. Zhao S, Mutch K, Elsone L, Nurmikko T, Jacob A. Neuropathic pain in neuromyelitis optica affects activities of daily living and quality of life. Mult Scler 2014;20: $1658-1661$ 


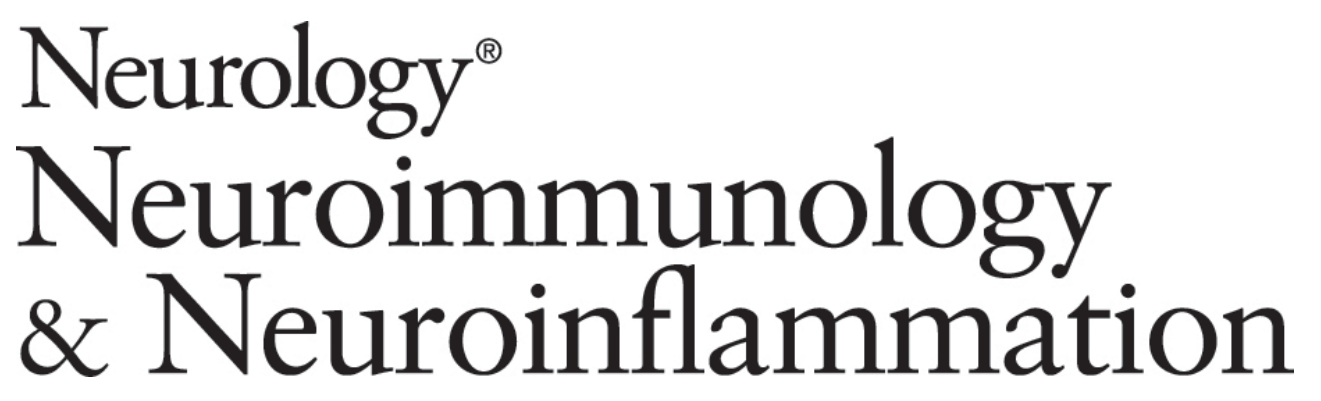

\author{
Collaborative International Research in Clinical and Longitudinal Experience Study in \\ NMOSD \\ Lawrence J. Cook, John W. Rose, Jessica S. Alvey, et al. \\ Neurol Neuroimmunol Neuroinflamm 2019;6; \\ DOI 10.1212/NXI.0000000000000583
}

This information is current as of June 28, 2019

Neurol Neuroimmunol Neuroinflamm is an official journal of the American Academy of Neurology.

Published since April 2014, it is an open-access, online-only, continuous publication journal. Copyright

Copyright $\odot 2019$ The Author(s). Published by Wolters Kluwer Health, Inc. on behalf of the American

Academy of Neurology.. All rights reserved. Online ISSN: 2332-7812.

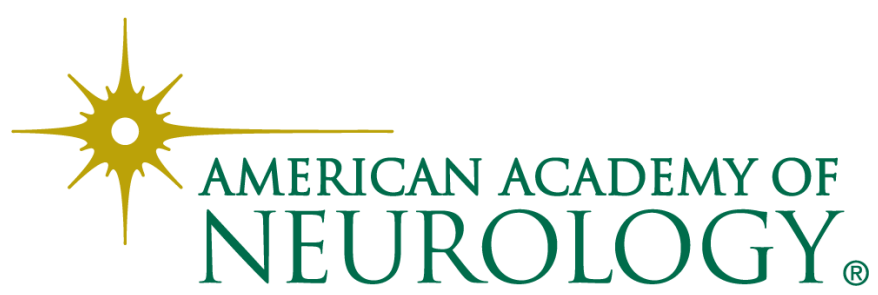




\section{Updated Information \& Services}

References

Citations

Subspecialty Collections

Permissions \& Licensing

Reprints including high resolution figures, can be found at: http://nn.neurology.org/content/6/5/e583.full.html

This article cites 39 articles, 1 of which you can access for free at: http://nn.neurology.org/content/6/5/e583.full.html\#\#ref-list-1

This article has been cited by 2 HighWire-hosted articles: http://nn.neurology.org/content/6/5/e583.full.html\#\#otherarticles

This article, along with others on similar topics, appears in the following collection(s):

All Demyelinating disease (CNS)

http://nn.neurology.org//cgi/collection/all_demyelinating_disease_cns Case control studies

http://nn.neurology.org//cgi/collection/case_control_studies

Optic neuritis; see Neuro-ophthalmology/Optic Nerve

http://nn.neurology.org//cgi/collection/optic_neuritis

Transverse myelitis

http://nn.neurology.org//cgi/collection/transverse_myelitis

Information about reproducing this article in parts (figures,tables) or in its entirety can be found online at:

http://nn.neurology.org/misc/about.xhtml\#permissions

Information about ordering reprints can be found online:

http://nn.neurology.org/misc/addir.xhtml\#reprintsus

Neurol Neuroimmunol Neuroinflamm is an official journal of the American Academy of Neurology.

Published since April 2014, it is an open-access, online-only, continuous publication journal. Copyright

Copyright $\odot 2019$ The Author(s). Published by Wolters Kluwer Health, Inc. on behalf of the American

Academy of Neurology.. All rights reserved. Online ISSN: 2332-7812.

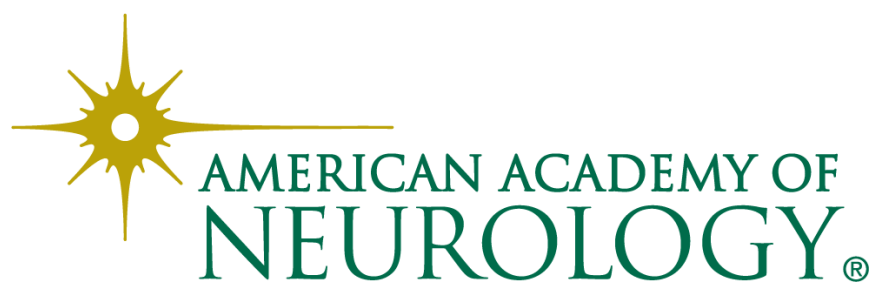

